\title{
The Role of Hydrothermal Activity in the Formation of Karst-Hosted Manganese Deposits of the Postmasburg Mn Field, Northern Cape Province, South Africa
}

\author{
Brenton J. Fairey ${ }^{1,+}$, Martin J. Timmerman ${ }^{2}$, Masafumi Sudo ${ }^{2}$ and Harilaos Tsikos ${ }^{3, *}$ \\ 1 School of Biological, Earth and Environmental Sciences, University College Cork, T23 TK30 Cork, Ireland \\ Institut für Erd-und Umweltwissenschaften, Universitat Potsdam, 14476 Potsdam, Germany \\ 3 Department of Geology, Rhodes University, Grahamstown 6139, South Africa \\ * Correspondence: h.tsikos@ru.ac.za \\ † Current address: Chemostrat Ltd., Welshpool SY21 8SL, UK
}

Received: 27 May 2019; Accepted: 28 June 2019; Published: 3 July 2019

\begin{abstract}
The Postmasburg Manganese Field (PMF), Northern Cape Province, South Africa, once represented one of the largest sources of manganese ore worldwide. Two belts of manganese ore deposits have been distinguished in the PMF, namely the Western Belt of ferruginous manganese ores and the Eastern Belt of siliceous manganese ores. Prevailing models of ore formation in these two belts invoke karstification of manganese-rich dolomites and residual accumulation of manganese wad which later underwent diagenetic and low-grade metamorphic processes. For the most part, the role of hydrothermal processes and metasomatic alteration towards ore formation has not been adequately discussed. Here we report an abundance of common and some rare Al-, Na-, K- and Ba-bearing minerals, particularly aegirine, albite, microcline, banalsite, sérandite-pectolite, paragonite and natrolite in Mn ores of the PMF, indicative of hydrothermal influence. Enrichments in $\mathrm{Na}$, $\mathrm{K}$ and/or $\mathrm{Ba}$ in the ores are generally on a percentage level for most samples analysed through bulk-rock techniques. The presence of As-rich tokyoite also suggests the presence of As and V in the hydrothermal fluid. The fluid was likely oxidized and alkaline in nature, akin to a mature basinal brine. Various replacement textures, particularly of $\mathrm{Na}$ - and $\mathrm{K}$ - rich minerals by Ba-bearing phases, suggest sequential deposition of gangue as well as ore-minerals from the hydrothermal fluid, with Ba phases being deposited at a later stage. The stratigraphic variability of the studied ores and their deviation from the strict classification of ferruginous and siliceous ores in the literature, suggests that a re-evaluation of genetic models is warranted. New Ar-Ar ages for K-feldspars suggest a late Neoproterozoic timing for hydrothermal activity. This corroborates previous geochronological evidence for regional hydrothermal activity that affected Mn ores at the PMF but also, possibly, the high-grade Mn ores of the Kalahari Manganese Field to the north. A revised, all-encompassing model for the development of the manganese deposits of the PMF is then proposed, whereby the source of metals is attributed to underlying carbonate rocks beyond the Reivilo Formation of the Campbellrand Subgroup. The main process by which metals are primarily accumulated is attributed to karstification of the dolomitic substrate. The overlying Asbestos Hills Subgroup banded iron formation (BIF) is suggested as a potential source of alkali metals, which also provides a mechanism for leaching of these BIFs to form high-grade residual iron ore deposits.
\end{abstract}

Keywords: manganese ore; Postmasburg manganese field; hydrothermal; karst; South Africa 


\section{Introduction}

Before the discovery of the manganese ore deposits of the Kalahari Manganese Field (KMF), the Postmasburg Manganese Field (PMF) was South Africa's largest producer of this important component of the steel industry [1]. The PMF deposits occur in two main belts (Figure 1), namely the Eastern and Western Belts, which stretch between Postmasburg in the south to Sishen in the north, a distance of approximately $65 \mathrm{~km}$. The Western Belt occurs in a north-south extending zone in close proximity to a regional unconformity and a regional thrust fault. The Eastern Belt forms an elongated, curved zone which predominantly develops along strike of a regional fold structure known as the Maremane Dome. A mixed type exists at the northern and southern extremities of the PMF.

The genesis of these typically irregular PMF ore bodies has been a topic of contention over a century of previous work (e.g., [2-9]). De Villiers [7] suggested a hydrothermal origin for the PMF ores, stating that the presence of, in particular, bixbyite, was indicative of high-grade metamorphism with fluids emanating from a putative magmatic source. De Villiers [10] suggested that bixbyite in these ores formed at temperatures ranging from $120{ }^{\circ} \mathrm{C}$ to $470{ }^{\circ} \mathrm{C}$. Nell et al. [11] also used bixbyite as a geothermometer but pointed to uncertainties in their methodology which is based on the distribution of iron in the bixbyite structure. Notwithstanding these uncertainties, Nell et al. [11] found that two bixbyite grains from the PMF recorded temperatures of formation at $315{ }^{\circ} \mathrm{C}$ and $370{ }^{\circ} \mathrm{C}$. Plehwe-Leisen [12] also estimated that the metamorphic temperatures for the PMF range between $350{ }^{\circ} \mathrm{C}$ and $400{ }^{\circ} \mathrm{C}$. These temperatures point to lower greenschist facies metamorphism in the area [1].

Plehwe-Leisen and Klemm [9] and Gutzmer and Beukes [1] have proposed genetic models that invoke karstification of manganiferous dolomites as the major ore-forming mechanism. In these models, the type of ore (i.e., siliceous versus ferruginous) is dependent upon the composition of the underlying dolomite, and little emphasis is placed on gangue phases and their potential to elucidate ore-forming processes. Moore et al. [13] described rare silicates such as sugilite, armbrusterite and norrishite as well as more common minerals such as albite and K-feldspar in Mn-rich occurrences above the Wolhaarkop breccia from Bruce iron ore mine, which all suggest alkali metasomatism producing complex gangue mineral assemblages in the PMF area. This prompted the need for further investigation of gangue minerals in other parts of the PMF. Concerning timing of metamorphism in the PMF, Gutzmer and Beukes [1] suggest an age of 1.8 to $1.9 \mathrm{Ga}$, coinciding with the Kheis Orogeny. The regional Blackridge thrust front on the western edge of the PMF is said to have formed during this time [1]. However, Van Niekerk [14] shows that the Kheis Terrane was deformed between 1.29 Ga and 1.17 Ga. In addition, a sugilite ${ }^{40} \mathrm{Ar}-{ }^{39} \mathrm{Ar}$ age of $620.2 \pm 3.3$ Ma determined by Moore et al. [13] suggests that a much later hydrothermal alteration event may have occurred in the area, possibly on a regional scale.

In this paper, we present new evidence for late Neoproterozoic hydrothermal fluid flow influencing the genesis of the PMF ore deposits. The hydrothermal activity has given rise to complex mineralogy of predominantly gangue phases, characterized by strong alkali enrichment and textures indicative of epigenetic fluid-rock interaction (vug filling, replacements, etc.). We show that the observed mineral assemblages are comparable not only to other nearby localities in the PMF, but also to the high-grade hydrothermal Mn deposits further afield (KMF), thus pointing to a likely regional-scale hydrothermal fluid-flow event. Finally, we present an adapted hydrothermal model for the development of the PMF ores that also accounts for the source of alkalis in these deposits. 


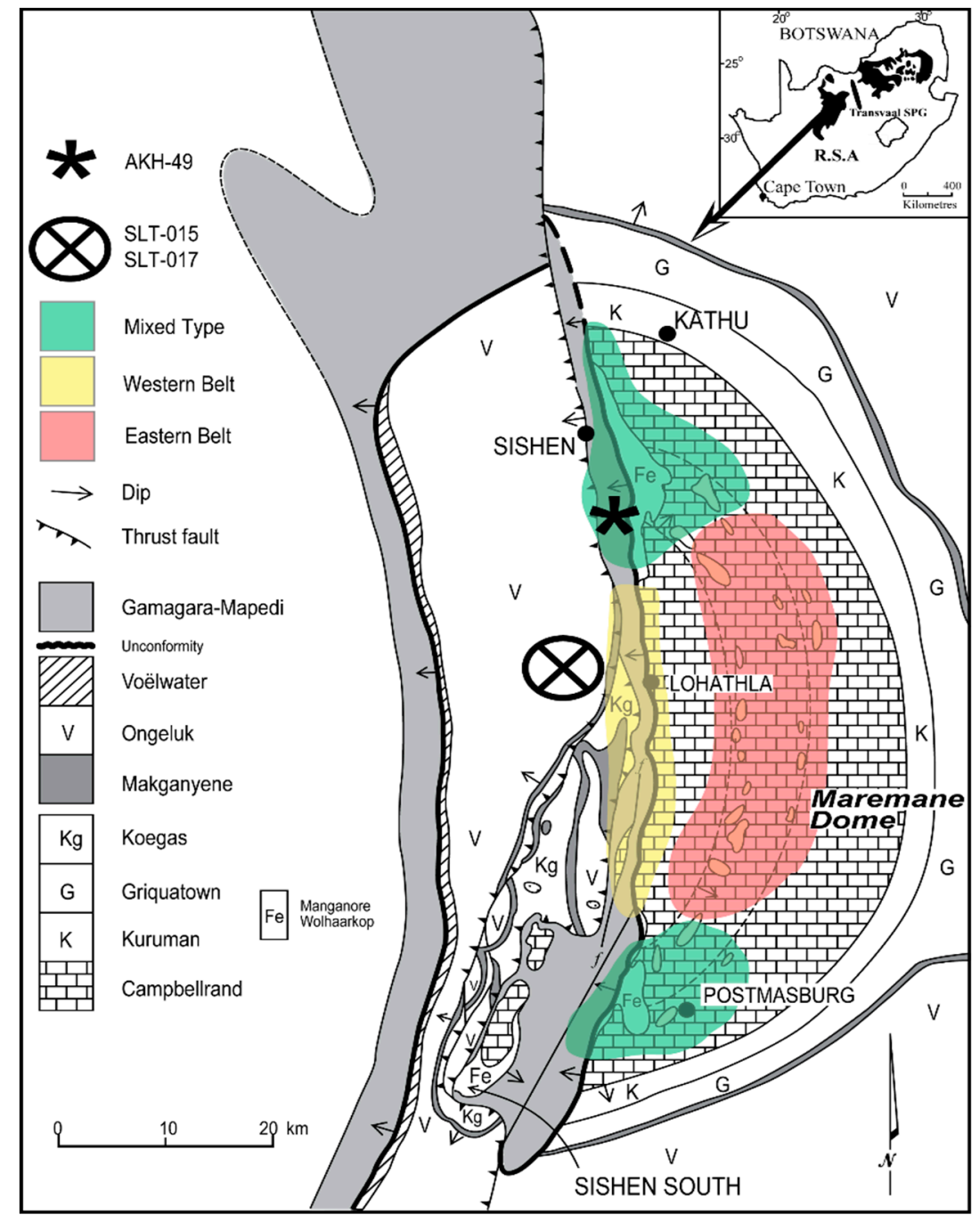

Figure 1. Regional geological map of the study area including general location of the studied drill cores as well as Postmasburg Manganese Field (PMF) ore-type distribution. Inset map shows distribution of Transvaal Supergroup in South Africa. Modified after $[9,13]$.

\section{Regional Geological Setting}

The Palaeoproterozoic Transvaal Supergroup is located in the Northern Cape Province of South Africa. It consists of the lower Ghaap and upper Postmasburg Groups (Table 1). The oldest subgroup in the Ghaap Group, the Schmidtsdrif Subgroup, comprises fluvial, shallow marine and intertidal arenites as well as platformal carbonates [15]. This is conformably overlain by a thick (1500-1700 m) succession of carbonates known as the Campbellrand Subgroup [16]. Beukes [16] defined two main facies in the Campbellrand Subgroup which are regionally divided by the Griquatown fault zone: the Ghaap Plateau facies and the Prieska facies. The Reivilo and Fairfield Formations of the Ghaap Plateau facies host the manganese ores of the PMF and are said to contribute manganese to the ensuing ore bodies [1,9].

The Reivilo Formation predominantly consists of stromatolitic to fenestral laminated dolomites [17] and is said to be chert-free [1]. The boundary between the Reivilo Formation and the overlying Fairfield Formation is defined by the development of the Kamden Member-a marker zone consisting of laminated dolomite overlain by banded iron-formation in the southern Ghaap Plateau facies [16]. The iron-formation pinches out toward the north with chert and ferruginous dolomite remaining [16]. However, Altermann and Siegfried's work [17] on a deep drill core through the Campbellrand dolomites near Kathu revealed that the Kamden Member can be absent altogether. The overlying, chert-bearing 
Fairfield Formation consists of flat pebble conglomerates and dolmicrites [17] with the upper boundary defined by a dolomite-clast breccia with a shale matrix [16]. This breccia signifies the base of the Klipfontein Heuwel Formation which consists of markedly silicified stromatolitic dolomites as well as chert beds [17].

The Asbestos Hills Subgroup comprises the Kuruman Iron-Formation, overlain by the upper Griquatown Iron-Formation. A solution collapse unconformity [1] exists regionally between the Campbellrand Subgroup and the overlying Kuruman Iron-Formation, and plays host to world-class massive hematite ores. The iron ores are thought to have formed upon slumping of Asbestos Hills banded iron-formation into karstic sinkhole structures; the strongly deformed BIF here is termed Manganore Iron Formation [18]. Dissolution of the manganese-bearing Campbellrand dolomite causes residual build-up of insoluble material (mainly chert, manganese and lesser iron) to form the Wolhaarkop breccia at the footwall of the collapsed iron ores $[1,9,13,17]$. The resultant stratigraphy shows typically a gradational contact between the lower Wolhaarkop breccia and the overlying Manganore Iron Formation [18]. This should then reflect an increasing Mn-Fe ratio with increasing depth in this zone.

The Ghaap Group is overlain by siliciclastic rocks and BIF of the Koegas Subgroup [19]. According to Beukes [15], a period of uplift and erosion led to the development of a regional unconformity between the Ghaap Group and the lowermost formation of the Postmasburg Group, namely the glacial Makganyene diamictite. The spatial scale of the unconformity, however, has been disputed by Polteau et al. [20] who reported field evidence of a conformable transition from the Koegas Subgroup to the overlying Makganyene Formation in some areas. The Makganyene Formation is overlain by sub-aqueously extruded lavas of the Ongeluk Formation [15]. New, recently published age constraints for the Ongeluk rocks at 2.43 Ga [21] negate an earlier published 2.2 Ga age by Cornell et al. [22], thus lending support to a conformable relationship between the 2.48 Ga Koegas Subgroup [19] and Makganyene Formation. Conformably overlying the Ongeluk Formation is the economically significant Hotazel Formation. This formation comprises three sedimentary manganese layers interbedded with BIF; these constitute the world class deposits of the KMF [23]. Carbonate rocks of the Mooidraai Formation $[24,25]$ locally overlie the Hotazel Formation strata.

Table 1. Simplified stratigraphy of the Transvaal Supergroup in the N. Cape Province of South Africa (adapted from Tsikos and Moore [23]).

\begin{tabular}{|c|c|c|c|c|}
\hline & & Subgroup & Formation & Predominant Lithology \\
\hline \multirow{9}{*}{$\begin{array}{c}\text { Transvaal } \\
\text { Supergroup }\end{array}$} & \multirow{4}{*}{$\begin{array}{l}\text { Postmasburg } \\
\text { Group }\end{array}$} & \multirow{2}{*}{ Voëlwater } & Mooidraai & $\begin{array}{l}\text { Carbonate with } \\
\text { minor chert }\end{array}$ \\
\hline & & & Hotazel & $\begin{array}{c}\text { Iron-formation with } \\
\text { intercalated manganese } \\
\text { ore layers }\end{array}$ \\
\hline & & & Ongeluk & Andesitic pillow lavas \\
\hline & & & Makganyene & Glacial diamictite \\
\hline & \multirow{5}{*}{ Ghaap Group } & Koegas & & Mudstones and wackes \\
\hline & & \multirow{2}{*}{ Asbestos Hills } & Griquatown & $\begin{array}{l}\text { Clastic textured } \\
\text { iron-formation }\end{array}$ \\
\hline & & & Kuruman & $\begin{array}{l}\text { Microbanded } \\
\text { iron-formation }\end{array}$ \\
\hline & & Campbellrand & & Various carbonate facies \\
\hline & & Schmidstdrif & & Mudstones and wackes \\
\hline
\end{tabular}

\section{Local Geology}

The PMF ores are generally separated into the Western and Eastern Belts (Figure 1). The Western Belt consists of ferruginous ores that developed in sinkholes in the Reivilo Formation, with deeper sinkholes hosting greater thicknesses of ore [1]. The hanging wall of these ores consists of Doornfontein 
conglomerates of the Gamagara Formation — the basal contact of which is gradual and conformable [1]. According to Plehwe-Leisen and Klemm [9], the Reivilo Formation underwent weathering and dissolution producing Mn-rich oozes in an open karst environment, before deposition of the Gamagara Formation. Manganese concentrations increase with increasing depth in the ore bodies [1,9]. Where the Doornfontein conglomerates are not developed above the manganese ore, iron-rich and occasionally aluminous-rich shales have been deposited [1].

The siliceous ores of the Eastern Belt are intimately associated with the Wolhaarkop chert breccia and the Fairfield Formation of the Campbellrand Subgroup [1]. The ore is capped by the Manganore Iron Formation which has slumped into the karstic sinkholes [1]. According to Gutzmer and Beukes [1], the matrix of the breccia is composed of quartz, hematite and braunite, becoming more siliceous and ferruginous toward the top and more manganiferous toward the base. Gutzmer and Beukes [1] describe transition zones between chert breccia and manganese ore bodies as gradual, and characterized by a rapid increase in the manganiferous matrix to chert fragment ratio.

Plehwe-Leisen and Klemm [9] describe a mixed ore type which occurs at the northern and southern ends of the Gamagara ridge. Gutzmer and Beukes [1], however, do not provide a separate characterization for this type as they consider it to be very similar to the Eastern Belt ore type. Plehwe-Leisen and Klemm [9] also show the mixed type ore bodies to be comparative to those of the Eastern Belt, with braunite being the major ore mineral developed in both Wolhaarkop breccia and intercalated shales. The Eastern Belt paragenesis is ascribed to the mixed type ores by Plehwe-Leisen and Klemm [9].

Samples were selected from diamond drill cores SLT-15, SLT-017 from the western sector of the Maremane anticline, obtained as part of a prospecting drilling campaign for iron ore mineralisation; and from drill core AKH49 from the Khumani iron ore mine (the latter previously sampled by Moore et al. [13]; Figure 1). Drill core SLT-015 shows the typical stratigraphy of the Eastern Belt ores with Wolhaarkop breccia at the base (Figure 2A). The base of the core consists of clast-supported Wolhaarkop breccia which grades into ferromanganese ore. The ore is unconformably overlain by shales and quartzites of the Mapedi Formation at the base of the Olifantshoek Supergroup [26]. This unconformity is the regional angular unconformity that is believed to be associated with widespread development of iron and manganese mineralisation at the PMF [27]. Thrusted over quartzite of the Mapedi Formation is andesitic lava of the Ongeluk Formation. This thrust forms part of the regional, NS-striking Blackridge thrust front. Finally, in the upper part of the drill core is four meters of Kalahari Group calcrete, the prevailing cover in the Northern Cape area. The depth at which the top of the orebody is intersected is around $80 \mathrm{~m}$ from the present surface, where surficial weathering is negligible to absent.

The sampled section in diamond drill core SLT-015 (Figure 2B) reaches a depth of approximately $98 \mathrm{~m}$ below surface, where the Wolhaarkop breccia is developed. The breccia shows a general fining-upward trend of chert clasts. At the base, the breccia is clast-supported with clasts consisting of chert and polyhedral quartz grains up to $1 \mathrm{~mm}$ in size (Figure 2C). From $97 \mathrm{~m}$ to $95 \mathrm{~m}$, the core consists of vuggy ferro-manganiferous matrix which grades back into clast-supported chert breccia with minor matrix until $92.5 \mathrm{~m}$. Here the breccia disappears almost entirely, giving way to vuggy ferro-manganiferous ore (Figure 2D). This grades into coarse-grained, highly vuggy manganese ore with abundant vug-filling, fine-grained, mostly whitish minerals (Figure 2E). At $91 \mathrm{~m}$, the vuggy texture of the ore gives way to massive ore with pods of coarse-grained manganiferous material as well as interstitial, dull brownish-red matrix. This ore persists until a depth of $88 \mathrm{~m}$ and also bears some brick-red, ferruginous lutite lenses as well as minor, very fine-grained pebble-rich layers. 


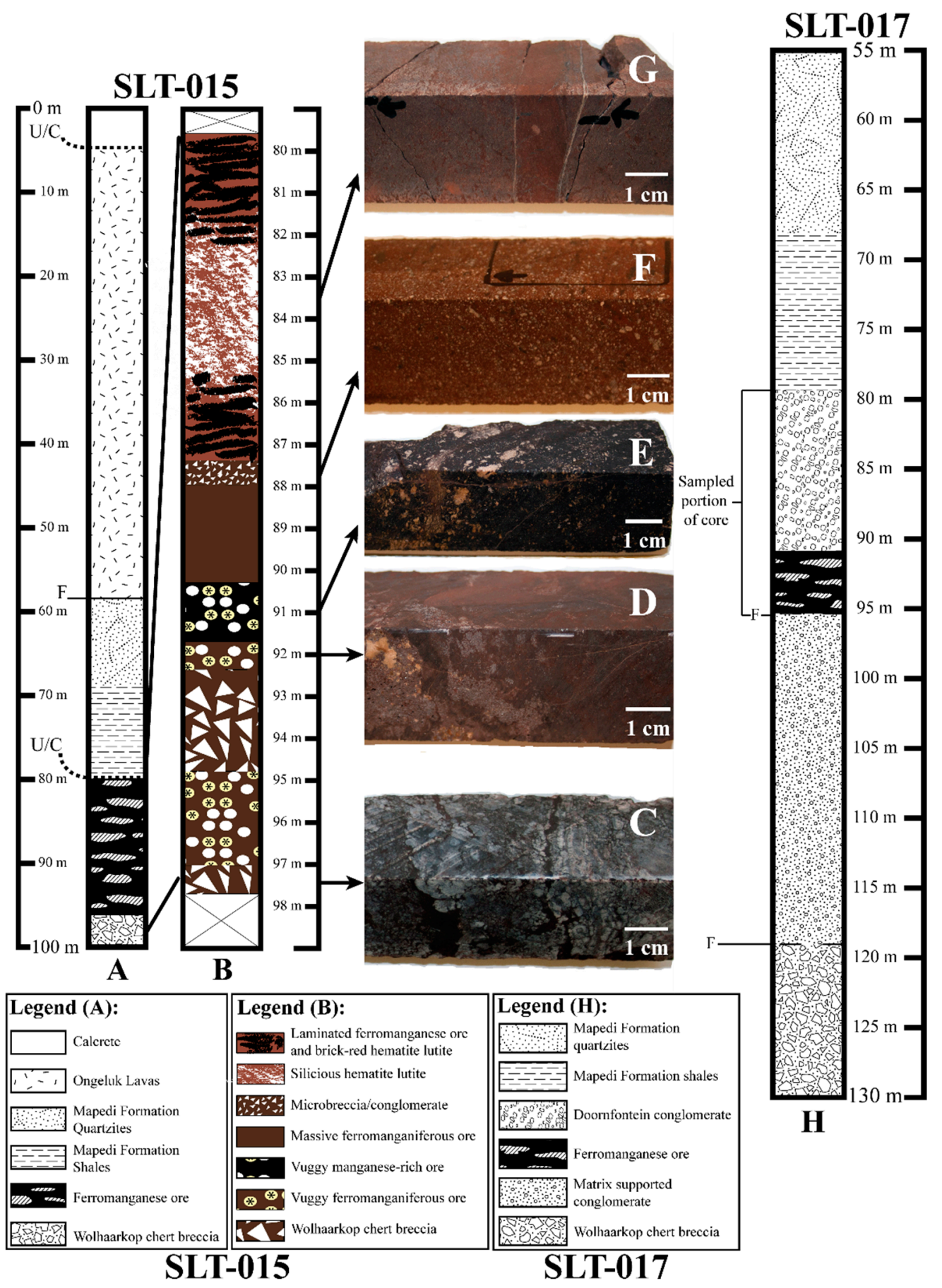

Figure 2. Drill core logs of the study intervals. (A) Simplified log of section SLT-015. (B) Detailed $\log$ of the lower portion of drill core SLT-015. (C) Clast-supported Wolhaarkop chert breccia (core photograph; sample 15-25). (D) Vuggy Fe-Mn ore (core photograph; sample 15-15P). (E) Vuggy Mn-rich ore (core photograph; sample 15-15I). (F) Microbreccia/conglomerate (core photograph; sample 15-11B). (G) Siliceous-ferruginous lutite (core photograph; sample 15-09). (H) Simplified log of entire section in SLT-017. Key: U/C, unconformity; F, fault.

The depth of $88 \mathrm{~m}$ is marked by the abundance of coarse (up to $2 \mathrm{~mm}$ ), light-coloured fragments in a fine-grained, brick-red matrix. This is interlayered with thin, massive, apparently manganese-rich layers. The top bed of this clast-bearing rock is approximately $10 \mathrm{~cm}$ thick and shows a fining-upward mode of the clasts until only matrix is present at $87.40 \mathrm{~m}$ (Figure 2F). This grades upwards into crudely 
laminated ore with darker, more ferro-manganiferous layers alternating with dark brick-red layers (assumed to be more siliceous due to the relatively lighter appearance). This laminated ore grades into dark brick-red, ferruginous lutite which contains a pervasive, very fine-grained greyish mineral (Figure 2G). Finally, the ferruginous lutite grades upwards into crudely laminated ferromanganese ore and brick-red lutite.

Drill core SLT-017 (Figure 2H) was selected due to the presence of ferromanganese ore as well as its stratigraphic resemblance to the upper portion of typical Western Belt ores with specific reference to the overlying Doornfontein Conglomerate. The bottom of the drill core is at a depth of $130 \mathrm{~m}$ below surface. From $130 \mathrm{~m}$ to $119 \mathrm{~m}$, the core consists of chert breccia with the number of chert clasts decreasing upwards. The matrix consists of black to dull brownish-red ferro-manganiferous wad. At $119 \mathrm{~m}$, core loss has occurred due to likely structural disturbance. The overlying $25 \mathrm{~m}$ consists of a matrix-supported conglomeratic facies. The clasts comprise quartz as well as BIF that shows occasional textural evidence of secondary hematite growth, set in a purple siliceous matrix. The upper contact of this conglomerate appears tectonic due to core loss and the presence of slickensides on some fragments at a depth of $95 \mathrm{~m}$.

Overlying the conglomerate is ferromanganese ore, comprising very fine-grained, laterally discontinuous "wispy" layers of alternating manganiferous and ferruginous material. The top of the orebody, at $90.85 \mathrm{~m}$, is marked by an abrupt contact with overlying ferruginous conglomerate. Clasts consist of oxidised BIF and range in outline from angular to well-rounded. The conglomerate gradually transitions to the overlying red shales. These red shales give way to purplish quartzite between $68 \mathrm{~m}$ and $65 \mathrm{~m}$. The quartzite at the top of the section contains minor interbedded conglomerates with oxidised banded iron-formation clasts. The remaining $55 \mathrm{~m}$ of core consist of shale and calcrete. The base of the ferromanganese ore upwards represents the expected stratigraphy for ferruginous ores of the Western Belt.

\section{Methods}

Polished thin sections and mounts were prepared at the Department of Geology at Rhodes University. Bulk rock powders, for X-ray diffraction (XRD) and X-ray fluorescence (XRF) analyses, were produced from samples composed of fine-grained matrix only. This was done by selecting approximately $50 \mathrm{~g}$ of homogenous matrix from quartered drill core samples. These were split into small pieces, handpicked and crushed to a fine powder using a swing mill and a hardened steel set and rings at the Department of Geology, Rhodes University.

A Bruker D8 Discover X-ray diffractometer, equipped with a Lynx Eye detector, was used to acquire bulk-rock powder XRD patterns in the Department of Chemistry, Rhodes University. Whole rock major and trace element concentrations were determined using a Philips PW1410 XRF spectrometer in the Department of Geology, Rhodes University. Mineral-specific elemental analyses were performed using a JEOL JXA 8230 Superprobe with 4 WD spectrometers also at the Department of Geology, Rhodes University.

Element maps were obtained from a polished thin section which was carbon coated in a Polaron CC 7650 carbon coater and an area selected for semi-quantitative X-ray compositional maps using a JEOL JXA- 8200 electron probe micro-analyser (EPMA) at the Institute of Geosciences of the University of Potsdam. The electron probe is equipped with five wavelength dispersive $\mathrm{X}$-ray spectrometers (WDS) and analytical conditions were a $15 \mathrm{kV}$ accelerating potential, a $35 \mathrm{nA}$ beam current and a $30 \mathrm{~ms}$ dwell time for each $1.3 \times 1.3 \mu \mathrm{m}$ interval. In total, four $1024 \times 850$ pixel images were generated for the thin section area of interest, in which the major element concentrations are depicted by different colours and colour intensities after calibration against a set of synthetic oxides and natural silicates obtained from the Smithsonian Institute.

In situ ultraviolet laser ablation (UVLA) ${ }^{40} \mathrm{Ar} /{ }^{39} \mathrm{Ar}$ dating of alkali feldspar from drill core SLT-015 was carried out at the geochronology laboratory of the Universität Potsdam, Germany. A disc was drilled out from the polished surface of a sample using a hollow cored $7 \mathrm{~mm}$ diameter mini-drill. 
The disc was ground down, polished and wrapped in commercial-grade aluminium foil before being placed in a sample container. Further details of all methods and archives of all analytical data not included in the main text, can be found in the Supplementary Materials.

\section{Petrography and Mineral Chemistry}

Most petrographic and mineral chemical work on the PMF has involved detailed observation of ore minerals (e.g., [28]). Other than the work by Moore et al. [13], little emphasis is placed upon gangue phases which may share key relationships with ore phases and provide further insight into ore-forming processes.

\subsection{Diamond Drill Core SLT-015}

Stratigraphic units in drill core SLT-015 have been distinguished based on hand specimen observations coupled with detailed petrographic, $\mathrm{XRD}$, and microprobe analyses.

Clast-supported chert breccia. Clasts are predominantly composed of chert as interlocking aggregates. However, coarse (up to $2 \mathrm{~mm}$ ), polyhedral quartz grains are also present as well as chalcedonic textures that typify void-filling processes (Figure $3 \mathrm{~A}$ ). The matrix predominantly consists of microscopically laminated hematite with minor hydrous iron oxides. Laminations tend to wrap around quartz and chert grains.

Matrix-supported, vuggy breccia. Vugs contain sérandite, microcline (var. adularia), witherite and quartz, as well as the rare species noélbensonite $\left(\mathrm{BaMn}_{2}{ }^{3+}\left(\mathrm{Si}_{2} \mathrm{O}_{7}\right)(\mathrm{OH})_{2} \cdot \mathrm{H}_{2} \mathrm{O}\right)$, tokyoite $\left(\mathrm{Ba}_{2} \mathrm{Mn}^{3+}\left(\mathrm{VO}_{4}\right)_{2}(\mathrm{OH})\right)$ and the first discovery of As-rich tokyoite (see [29] and Figure 3B). In places, pseudomorphous replacement of sérandite by witherite (inset Figure 3C) and apparent replacement of sérandite by noélbensonite and As-rich tokyoite (Figure 3C) can be observed.

The matrix consists of fine-grained, manganese-bearing hematite and, to a lesser extent, aluminium-bearing braunite. Subordinate unidentified hydrous iron oxide phases are also present. This matrix is mostly finely laminated but botryoidal textures also exist, as well as hematite micro-concretions enveloped by manganese-bearing, hydrous iron oxide. Micro-analyses of hematite across the entire sampled section of drill core SLT-015 reveals varying compositions, particularly for $\mathrm{Mn}_{2} \mathrm{O}_{3}$ and $\mathrm{Fe}_{2} \mathrm{O}_{3}$, which tend to substitute for one another in the hematite structure (Table 2).

Table 2. Average composition of hematite in drill core SLT-015.

\begin{tabular}{cccc}
\hline Oxide wt. \% & $\boldsymbol{n = 1 4}$ & STD & Range \\
\hline $\mathrm{TiO}_{2}$ & 0.10 & 0.08 & $<0.016-0.21$ \\
$\mathrm{Al}_{2} \mathrm{O}_{3}$ & 0.48 & 0.54 & $0.02-1.72$ \\
$\mathrm{SiO}_{2}$ & 0.57 & 0.10 & $0.43-0.74$ \\
$\mathrm{Fe}_{2} \mathrm{O}_{3}$ & 94.45 & 2.19 & $90.35-97.27$ \\
$\mathrm{Mn}_{2} \mathrm{O}_{3}$ & 4.13 & 2.03 & $0.12-6.86$ \\
$\mathrm{Cr}_{2} \mathrm{O}_{3}$ & 0.01 & 0.02 & $<0.010-0.04$ \\
Total & 99.75 & 0.99 & $98.14-100.64$ \\
\hline \multicolumn{5}{c}{ Cations based on 3 oxygens: } \\
$\mathrm{Ti}$ & 0.00 & \\
$\mathrm{Al}$ & 0.02 & \\
$\mathrm{Si}$ & 0.02 & \\
$\mathrm{Fe}$ & 1.88 & \\
$\mathrm{Mn}$ & 0.08 & \\
$\mathrm{Cr}$ & 0.00 &
\end{tabular}

$\mathrm{STD}=$ standard deviation; $\mathrm{n}$ = number of analyses. 


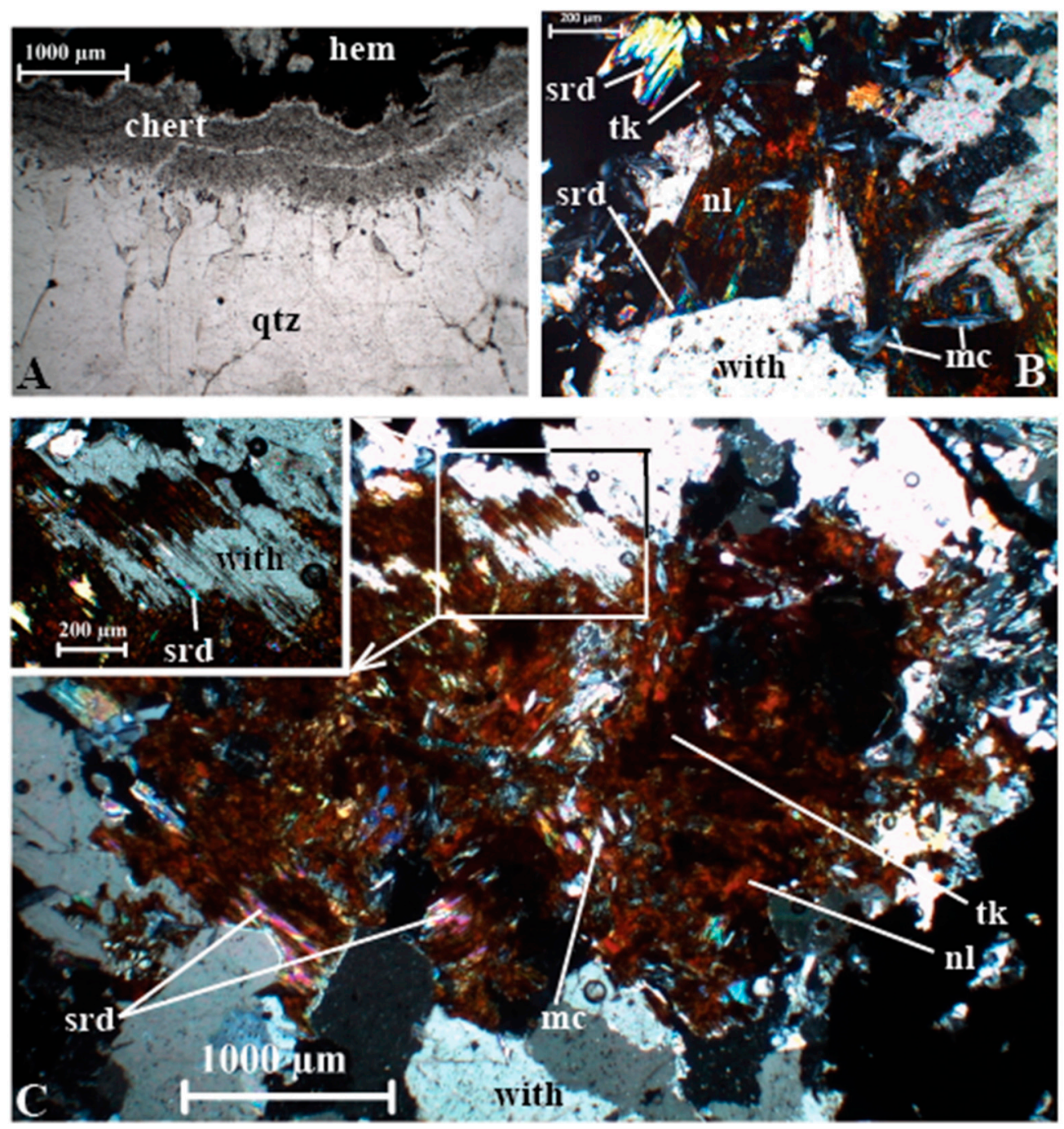

Figure 3. Photomicrographs from the base of drill core SLT-015. A. Void-filling polyhedral quartz (qtz) fining toward the void boundary which is in turn lined by chalcedony in a hematite (hem)-dominated matrix (PPL, sample 15-26A). B. Minor subhedral sérandite (srd) adjacent to As-rich tokyoite (tk) and noélbensonite (nl). Pseudomorphous replacement of sérandite by witherite is shown in the lower centre of the image (XPL, sample 15-23). C. Aggregated noélbensonite and As-rich tokyoite surrounded by euhedral, coarse-grained (up to $1000 \mu \mathrm{m}$ ) witherite (with). The lower part of the image shows sérandite replaced by As-rich tokyoite and noélbensonite. Inset shows pseudomorphous witherite after sérandite with minor relict sérandite laths. Fine-grained $(<100 \mu \mathrm{m})$ microcline $(\mathrm{mc})$ adularia are randomly distributed within the vug (XPL, sample 15-23).

Aegirine-augite-bearing, clast-supported breccia. Matrix-supported breccia grades back into clast-supported breccia. Micro-crystalline chert and coarse-grained, anhedral to subhedral, zoned quartz are present here. The matrix consists of platy hematite and hydrous iron oxide exhibiting a variety of colloform textures. A mineral of the aegirine-augite solid solution series occurs toward the top of the unit as extremely fine-grained aggregates in small vugs, and as fine-grained, acicular, aggregated grains growing outwards from the walls of quartz-filled vugs.

Aegirine-rich, matrix-supported breccia. Clast-supported breccia gives way to matrix-supported breccia with an abundance of vug-filling minerals. Chert is absent in this zone but coarse-grained quartz is present in vugs. Fine-grained $(<50 \mathrm{~m})$ aegirine aggregates line the boundaries of most vugs, with quartz generally forming the inner core and aegirine blades radiating outward from aggregations (Figure 4A). Aegirine compositions from Wessels Mine in the KMF are very similar to those in drill core 
SLT-015 (Table 3). In aegirine-rich samples, the matrix contains approximately 10 wt. \% sodium. Given the amount of silicon in the matrix (ca. $36 \mathrm{wt}$. \%), almost all of the sodium can be accounted for by $68 \%$ modal aegirine. In other vugs, microcline forms the outer zone with sérandite in the centre (Figure 4B). However, the bulk of sérandite found in SLT-015 occurs as radial aggregates, often pseudomorphously replacing euhedral quartz grains (Figure 4C). Aegirine-dominated vugs are rare. The size of these vugs appears to control the grain size of the aegirine within them (Figure 4D). Coarse-grained aegirine appears to only occur in the centre of larger vugs. The presence of albite with inclusions of sérandite suggests precipitation of albite after sérandite (Figure 4E). Coarse-grained (average $200 \mu \mathrm{m}$ ), anhedral albite also occurs in this unit, with single grains filling small voids and taking on the void shape. Noélbensonite is also present, predominantly occurring as very fine-grained $(<20 \mu \mathrm{m})$ aggregated needles (Figure 4F).
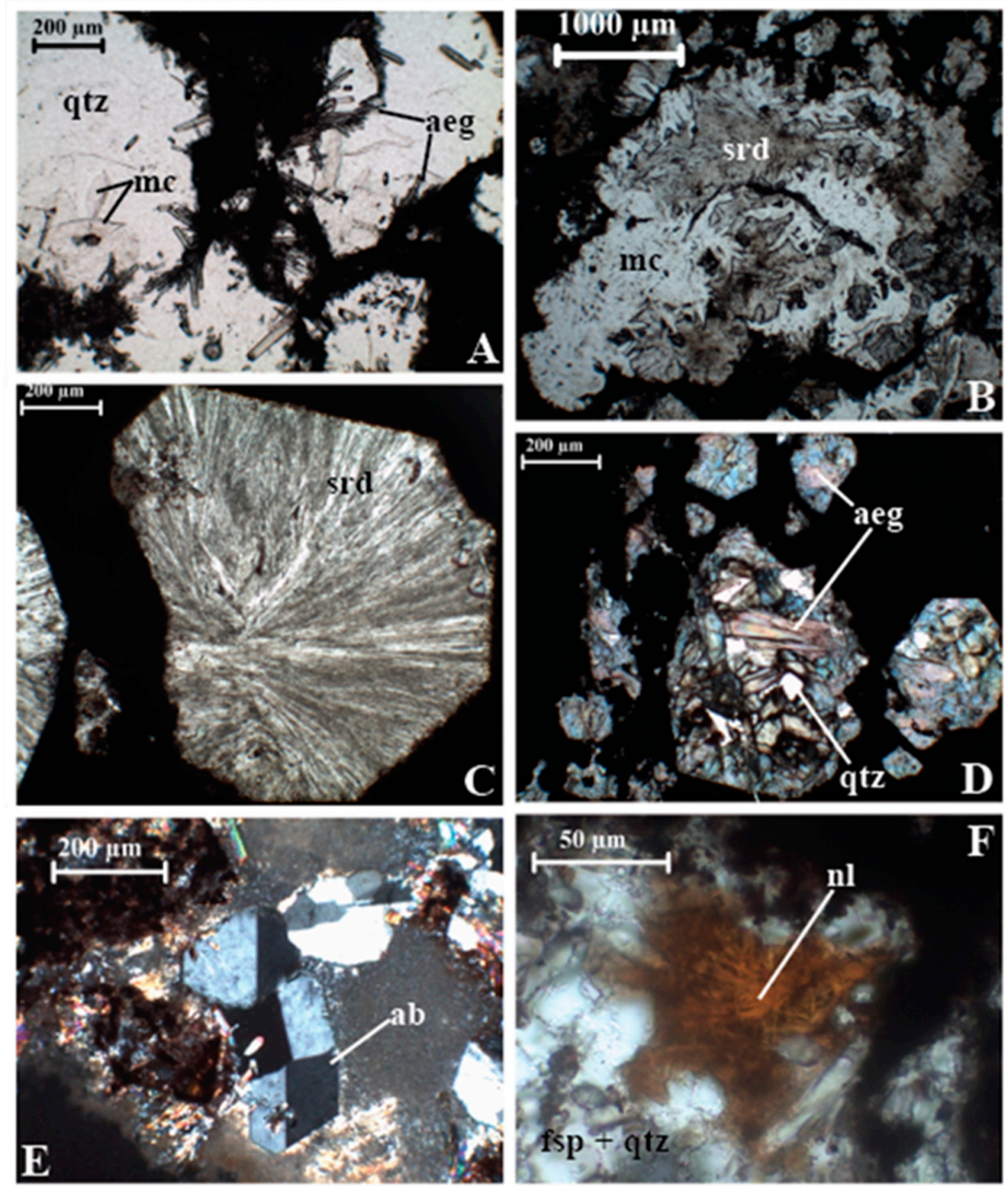

Figure 4. Typical textures observed in the matrix-supported breccia overlying the uppermost clast-supported breccia in drill core SLT-015. A. Blades of aegirine (aeg) growing inward from vug boundaries. Microcline (mc) adularia and quartz (qtz) are also present (PPL, sample 15-15Q). B. Vug consisting of microcline toward the edges and sérandite (srd) toward the centre. (PPL, sample 15-15O). C. Pseudomorphous sérandite after quartz (PPL, sample 15-15Q). D. Aegirine filling smaller vugs with minor quartz. Also shows the distinct pale brown to blue pleochroism typical of aegirine (PPL, sample 15-15Q). E. Albite (ab) showing Carlsbad twins. (XPL, sample 15-15Q). F. Aggregated needles of noélbensonite (nl) adjacent to quartz and feldspar (fsp) as found toward the middle and top of the stratigraphy in drill core SLT-015 (PPL, sample 15-15Q). 
Vuggy manganese ore. Overlying the aegirine-rich, matrix-supported breccia unit lies approximately one meter of extremely vuggy manganese ore (Figure 2E). In this unit, braunite and hematite are the dominant ore minerals, with vugs filled with various silicate (sérandite, feldspar, quartz), sulphate (barite) and carbonate (witherite, strontianite) phases. Fine-grained strontianite can be found as inclusions in barite vugs and veins and replacing witherite along grain boundaries. Sérandite also occurs in vugs and as a replacement of quartz. Minor modal amounts of aegirine occur as coarse-grained (up to $1 \mathrm{~mm}$ ) vug-fills. One sample in this unit contains large, angular vugs that have cores of coarse-grained (up to $2 \mathrm{~mm}$ ) calcite and rims of finer-grained albite ( $500 \mu \mathrm{m})$ in a matrix of crystalline braunite (Figure 5A and inset). Here, albite and natrolite can also be found as the only minerals occupying smaller vugs.
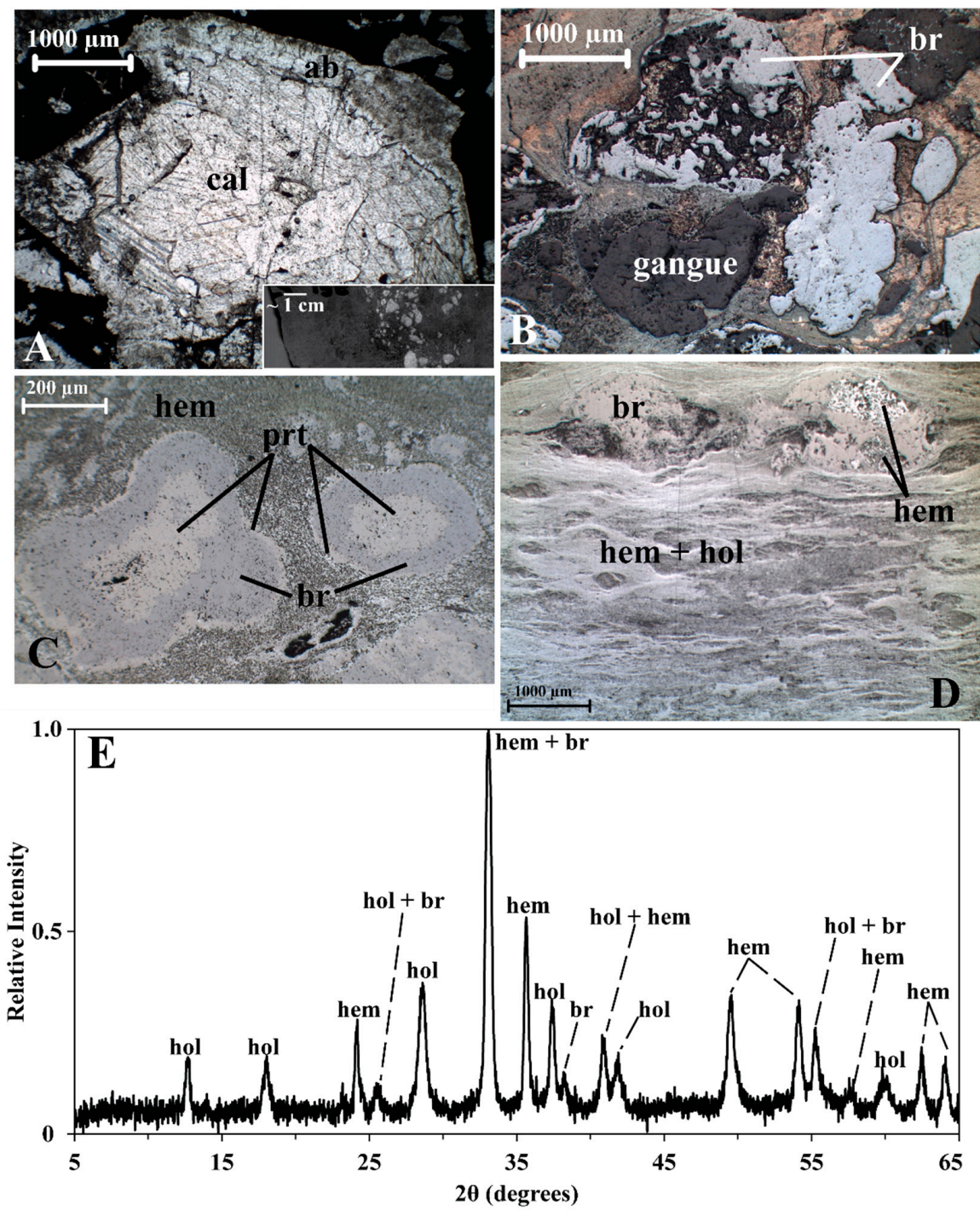

Figure 5. Petrographic characteristics of the extremely vuggy crystalline manganese and massive ferromanganiferous ore units. A. Zoned vugs with cores of coarse-grained calcite (cal) and rims of albite (ab) (PPL, sample 15-15E); Inset: Sample 15-15E in hand specimen. B. Zoned manganese concretions with inner and outer zones consisting of partridgeite (prt) and a middle zone of braunite (br). The surrounding matrix consists of cryptoplaty hematite (Reflected light, PPL, sample 15-15E). C. Various stages of replacement of calcite-albite-filled vugs with fine-grained braunite (Reflected light, PPL, sample 15-15E). D. Laminated cryptoplaty hematite and hollandite (hol) in sample 15-13. Laterally discontinuous laminae wrap around braunite(br)-rich (with microplaty hematite) clasts. E. Whole rock powder XRD spectrum of matrix showing presence of hollandite, braunite and hematite (sample 15-13). 
The highly porous matrix is characterised by unfilled vugs in the interstices between hematite plates as well as between and within braunite and partridgeite grains. Concentrically zoned manganese concretions identified in this unit have a partridgeite inner and outer zone and an intervening zone of braunite (Figure 5B). These localised concretions occur in a matrix of crypto-platy hematite adjacent to massive, crystalline braunite and partridgeite. Where vugs consist of calcite and albite, some vug-fills are either partially or completely replaced by fine-grained braunite (Figure 5C). The entire replacement process is seen in this image, from unaffected gangue phases to partial replacement and finally to complete replacement of gangue vug-fills by braunite.

Massive ferromanganese ore. Reflected light microscopy reveals that this unit is microscopically laminated in places and that vugs are still present but not abundant. Parts of this unit show coarse-grained crystalline hematite. However, the most common textural feature is that of extremely finely laminated, crypto-platy hematite and hollandite (Figure 5D). Hollandite is a Ba-Mn oxide that is generally associated with supergene alteration but has also been found in contact-metamorphic manganese ores [30]. In this ore type, monomineralic clasts of braunite can be found in a matrix of laminated crypto-platy hematite and hollandite (matrix grain size $<10 \mu \mathrm{m}$ ), where laterally discontinuous laminae have draped around the clasts. Microplaty hematite appears to be replacing the braunite-rich clasts in this case. A bulk rock powder X-ray diffraction spectrum of the matrix of this unit confirms the presence of hollandite, hematite and braunite (Figure 5E).

Fine-grained breccia. A $60 \mathrm{~cm}$ thick unit of fine-grained breccia overlies the massive ferro-manganiferous unit (Figure 2F). What appear to be breccia clasts in hand specimen are shown to be mineral-filled vugs under a microscope. Quartz is one of the major constituents of the vugs, where it generally occurs as the central core surrounded by natrolite (Figure 6A). Although Gottardi and Galli [31] classify natrolite as a fibrous zeolite, Vlasov et al. [32], for instance, point out that various crystal habits of the mineral exist in the Lovozero massif. These habits range from prismatic, to fibrous, to acicular and even to chalcedonic [32]. Vlasov et al. [32] also describe a fine-grained granular habit for natrolite, similar in appearance to that found in drill core SLT-015. In this study, it is also found as medium-grained, anhedral crystals in some vugs where it is the dominant phase. In this case, it can contain fine sérandite inclusions.

Table 3. Average aegirine composition of 19 microprobe analyses in drill core SLT-015 as well a single analysis of aegirine from Wessels Mine and an analysis of matrix in sample 15-15N *.

\begin{tabular}{ccccc}
\hline Oxide wt. \% & $n=\mathbf{1 9}$ & STD & Wessels $^{\mathbf{1}}$ & 15-15N Matrix \\
\hline $\mathrm{SiO}_{2}$ & 52.24 & 0.34 & 52.36 & 36.57 \\
$\mathrm{Al}_{2} \mathrm{O}_{3}$ & 0.53 & 0.38 & 0.04 & 0.33 \\
$\mathrm{Fe}_{2} \mathrm{O}_{3}$ ** & 30.54 & 1.61 & 29.92 & 49.36 \\
$\mathrm{MnO}^{* *}$ & 1.04 & 0.59 & n.d & 1.37 \\
$\mathrm{Mn}_{2} \mathrm{O}_{3}$ & n.d & & 2.21 & n.d \\
$\mathrm{MgO}$ & 0.26 & 0.46 & 0.24 & 0.15 \\
$\mathrm{CaO}$ & 0.28 & 0.45 & 0.46 & 0.13 \\
$\mathrm{Na}{ }_{2} \mathrm{O}$ & 13.97 & 0.40 & 14.00 & 10.82 \\
$\mathrm{~K}_{2} \mathrm{O}$ & 0.04 & 0.05 & n.d & 0.05 \\
$\mathrm{Total}$ & 98.86 & 0.58 & 99.19 & 98.80 \\
\hline \multicolumn{5}{c}{ Cations based on 6 oxygens: } \\
\hline $\mathrm{Si}$ & 2.02 & & 2.02 & \\
$\mathrm{Al}$ & 0.02 & & 0.00 & \\
$\mathrm{Fe}$ & 0.89 & & 0.87 & \\
$\mathrm{Mn}$ & 0.03 & & 0.07 & \\
$\mathrm{Mg}$ & 0.02 & 0.01 & \\
$\mathrm{Ca}$ & 0.01 & & 0.02 & \\
$\mathrm{Na}$ & 1.05 & & 1.05 & \\
$\mathrm{~K}$ & 0.00 & & - &
\end{tabular}

${ }^{1}$ microprobe analysis of aegirine by Dixon [33]; ${ }^{*}$ The matrix was analysed as a mixed analysis of fine-grained material using a microprobe beam diameter of $10 \mu \mathrm{m}$; ${ }^{* *}$ Total $\mathrm{Fe}_{\text {as }} \mathrm{Fe}_{2} \mathrm{O}_{3}$, total $\mathrm{Mn}$ as $\mathrm{MnO}$; n.d = not determined; $n=$ number of analyses. 

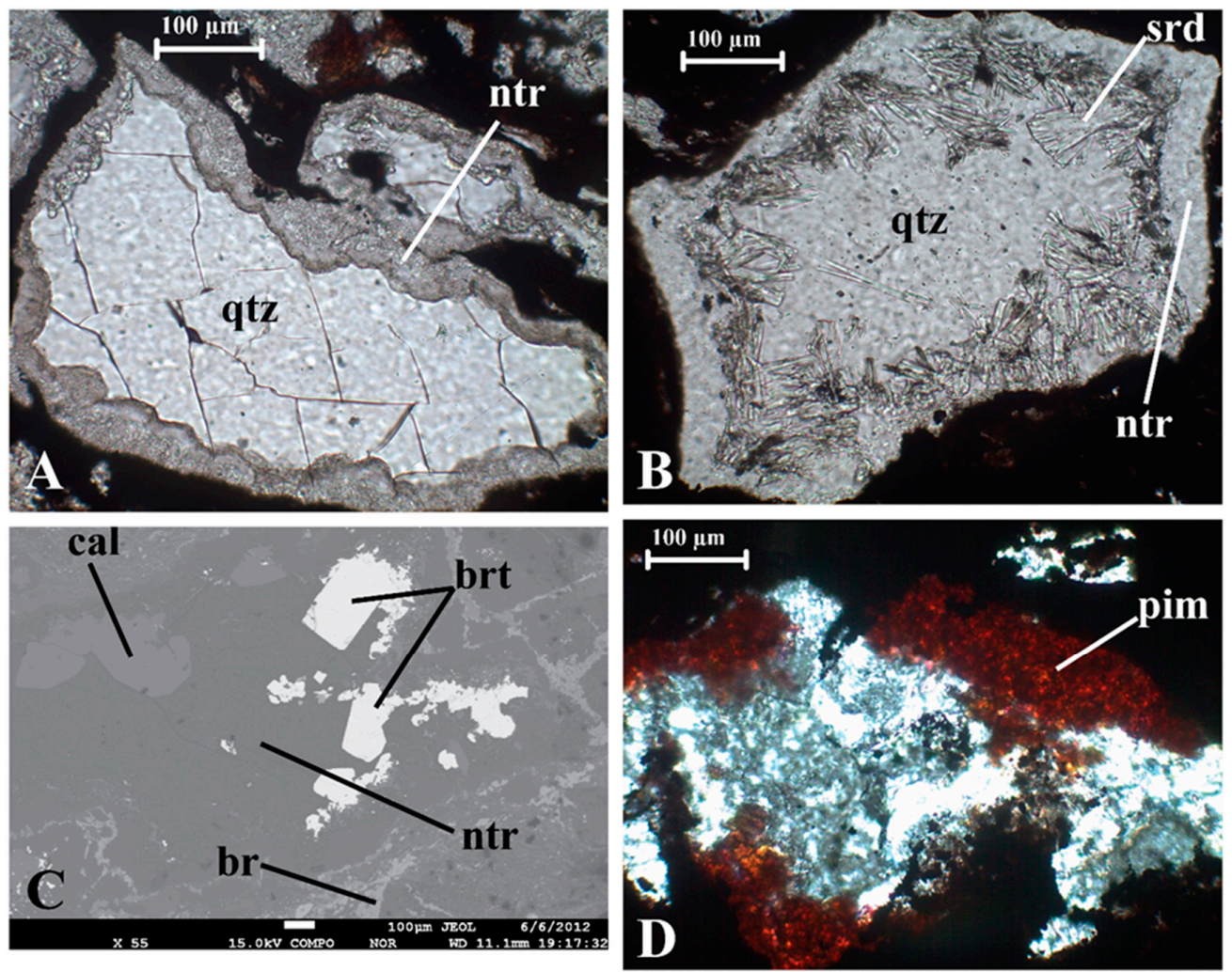

Figure 6. Various textures and mineral relationships as observed in the fine-grained breccia unit in drill core SLT-015. All images are transmitted light photomicrographs unless otherwise stated. A. Fractured quartz (qtz) grain replaced at the boundary by natrolite (ntr) (PPL, sample 15-11Ci). B. Mineral zonation in a vug with a core of quartz, an inner zone of sheaf-like aggregates of sérandite (srd) and an outer zone of natrolite. (PPL, sample 15-11B). C. Backscattered electron image of a barite(brt)-calcite(cal)-natrolite vug in a braunite(br)-rich matrix (sample 15-11B). D. Fine aggregates of piemontite (pim) along a vug boundary, in contact with opaque matrix (XPL, sample 15-11Cii).

Many vugs display a distinct phase zonation where sheaf-like aggregates of sérandite grow inward into a core of quartz (Figure 6B). The outer zone consists of fine-grained, aggregated natrolite and albite. Barium phases are present in this unit, forming part of the complex mineralogy of these vugs. The principal Ba-phase is barite which occurs as euhedral, blocky to columnar grains (Figure 6C). Very fine-grained braunite (Figure 6C) and hematite occurs in the matrix of this unit. Calcite occurs in some vugs but is not abundant. Another accessory phase that occurs in this unit is the manganese-bearing epidote piemontite which appears as fine-grained, reddish brown aggregates at vug boundaries in contact with the opaque matrix (Figure 6D)

Piemontite typically occurs in rocks which are associated with low-grade metamorphism but it can also be produced by hydrothermal activity within manganese deposits [34]. Piemontite, as well as Sr-piemontite, is also found in the Kalahari Manganese Field [35]. Piemontite in this unit has low Fe content and high $\mathrm{Mn}$ and $\mathrm{Al}$ content (Table 4). Other phases that are present in the microbreccia unit include minor pectolite and barytocalcite. These accessory phases occur only within vugs. Pectolite tends to occur as fine, blocky aggregates or laths that appear to grow from the vug boundaries toward the centre. The pectolite in this study is easily distinguishable from sérandite in the thin section as it is brown in plane-polarized light. This unit contains the highest abundance of Ba-rich species in drill core SLT-015. Witherite and barite occur in more than one unit in drill core SLT-015 but barytocalcite has only been found in the microbreccia unit. 
Table 4. Average composition of natrolite, piemontite and paragonite from drill core SLT-015. Also shown is the composition of paragonite from Zen et al. [36].

\begin{tabular}{|c|c|c|c|c|c|c|c|}
\hline \multirow[b]{2}{*}{ Oxide wt. \% } & \multicolumn{2}{|c|}{ Natrolite } & \multicolumn{2}{|c|}{ Piemontite } & \multicolumn{2}{|c|}{ Paragonite } & \multirow{2}{*}{$\begin{array}{c}\text { Paragonite } \\
\text { Zen et al. [36] }\end{array}$} \\
\hline & $n=11$ & STD & $n=3$ & STD & $n=6$ & STD & \\
\hline $\mathrm{SiO}_{2}$ & 47.01 & 0.52 & 38.57 & 0.28 & 48.76 & 0.43 & 47.00 \\
\hline $\mathrm{Al}_{2} \mathrm{O}_{3}$ & 26.20 & 0.15 & 22.03 & 0.42 & 37.54 & 0.18 & 39.10 \\
\hline $\mathrm{TiO}_{2}$ & n.d & & 0.06 & 0.01 & 0.00 & 0.00 & 0.02 \\
\hline $\mathrm{Fe}_{2} \mathrm{O}_{3}$ & n.d & & 1.17 & 0.08 & n.d & & 0.78 \\
\hline $\mathrm{FeO}$ & 0.03 & 0.04 & n.d & & 0.56 & 0.40 & - \\
\hline $\mathrm{Mn}_{2} \mathrm{O}_{3}$ & n.d & & 15.02 & 0.44 & n.d & & - \\
\hline $\mathrm{MnO}$ & 0.09 & 0.18 & n.d & & 0.06 & 0.02 & 0.02 \\
\hline $\mathrm{MgO}$ & n.d & & 0.02 & 0.02 & 0.03 & 0.01 & 0.10 \\
\hline $\mathrm{CaO}$ & 0.02 & 0.01 & 21.52 & 0.27 & 0.03 & 0.01 & 0.24 \\
\hline $\mathrm{Na}_{2} \mathrm{O}$ & 16.05 & 0.21 & 0.23 & 0.09 & 5.31 & 0.17 & 7.50 \\
\hline $\mathrm{K}_{2} \mathrm{O}$ & 0.03 & 0.02 & 0.05 & 0.02 & 0.44 & 0.06 & 0.81 \\
\hline $\mathrm{Cr}_{2} \mathrm{O}_{3}$ & & & & & 0.02 & 0.02 & - \\
\hline $\mathrm{H}_{2} \mathrm{O}$ & n.c & & 1.89 & 0.01 & n.c & & 4.3 \\
\hline Total & 89.42 & 0.81 & 100.56 & 0.34 & 92.75 & 0.36 & 95.57 \\
\hline \multicolumn{8}{|c|}{ Cations based on $10 \mathrm{O}$ for natrolite, $12.5 \mathrm{O}$ for piemontite and $11 \mathrm{O}$ for paragonite: } \\
\hline $\mathrm{Si}$ & 3.01 & & 3.05 & & 3.16 & & 3.00 \\
\hline $\mathrm{Al}$ & 1.98 & & 2.05 & & 2.86 & & 2.94 \\
\hline $\mathrm{Ti}$ & & & 0 & & 0.00 & & 0.00 \\
\hline $\mathrm{Fe}^{3+}$ & & & 0.07 & & & & 0.04 \\
\hline $\mathrm{Fe}^{2+}$ & 0.00 & & & & 0.03 & & \\
\hline Mn & 0.01 & & 0.9 & & & & \\
\hline $\mathrm{Mg}$ & & & 0 & & 0.00 & & 0.01 \\
\hline $\mathrm{Ca}$ & 0.07 & & 1.82 & & 0.00 & & 0.02 \\
\hline $\mathrm{Na}$ & 1.99 & & 0.03 & & 0.67 & & 0.93 \\
\hline K & 0.00 & & 0.01 & & 0.04 & & 0.07 \\
\hline $\mathrm{Cr}$ & & & & & 0.00 & & \\
\hline
\end{tabular}

$n=$ number of analyses; $\mathrm{n} . \mathrm{c}=$ not calculated $; \mathrm{n} . \mathrm{d}=$ not determined $; \mathrm{STD} .=$ standard deviation.

Siliceous hematite lutite and laminated ferromanganese ore. Two units exist in the upper portion of the study interval in drill core SLT-015 (Figure 2). The first unit consists of hematite lutite. Transmitted light microscopy (Figure 7A) shows that fine-grained $(<10 \mu \mathrm{m})$, aggregated mica is also present. Bulk rock XRD analysis reveals peaks at $2 \theta$ angles consistent with paragonite (Figure $7 \mathrm{C}$ ). However, the intensities of the respective peaks are not consistent with data from the literature. Average chemical analyses of the mineral are given in Table 4 . Sodium and aluminum concentrations are lower than typical paragonite [36] but this could be explained by a non-stoichiometric structure for the paragonite in this study, with vacancies in the Na site. This also explains the irregular peak intensities for paragonite in SLT-015. Paragonite is typically associated with greenschist-, amphibolite- and blueschist-facies metamorphic rocks, occurring as fine-grained aggregates, but can also be found in fine-grained sedimentary rocks [34]. Hematite contributes the bulk of the opaque matrix in this unit. 

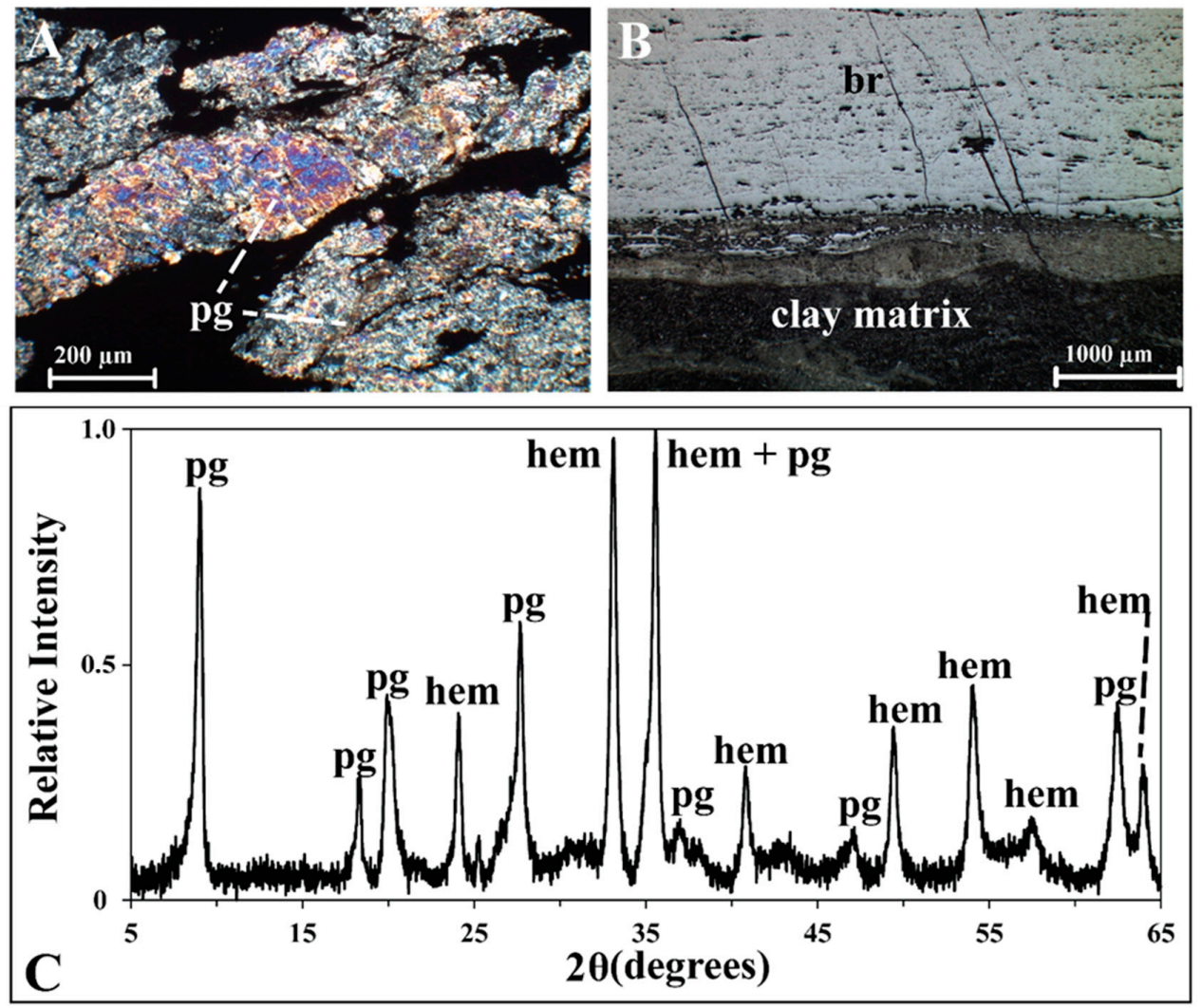

Figure 7. Petrographic character of the upper portion of drill core SLT-015. A. Transmitted light photomicrograph of fine-grained paragonite (pg) (XPL, sample 15-09). B. Fine-grained, crystalline braunite (br) laminations alternating with extremely fine-grained, hematite-bearing lutite laminations (reflected light, PPL, sample 15-02). C. Whole rock powder XRD spectrum of sample 15-09 highlighting the presence of two major phases: paragonite (pg) and hematite (hem).

The second unit in the upper portion of SLT-015 consists of laminated ferromanganese ore with intercalated lenses of brick-red, hematite-rich (ferruginous) lutite. Reflected-light microscopy reveals similar features to those seen in hand specimen. The broad textural appearance of this unit consists of massive, fine-grained, crystalline braunite laminations which alternate with extremely fine-grained, hematite-bearing lutite (Figure 7B). The very fine-grained $(<10 \mu \mathrm{m})$ hematite accounts for the brick-red colour of the matrix. Some parts of this unit show alternating monomineralic laminations of fine-grained $(<50 \mu \mathrm{m})$ hematite and braunite. Discrete silicate phases cannot be observed under the microscope here, but bulk-rock XRD analysis of the clay matrix from a representative sample reveals the presence of both hematite and paragonite.

\subsection{Diamond Drill Core SLT-017}

Due to faulting, only the upper part of the ferromanganese ore body is preserved in drill core SLT-017. The hanging wall of the ore body in SLT-017 consists of ferruginous conglomerates of the Doornfontein Conglomerate-this relationship is typical of Western Belt, ferruginous ores [1].

The ferromanganese ore shows textural and mineralogical consistency throughout the orebody. It is, for the most part, very fine-grained $(<20 \mu \mathrm{m})$ and generally consists of laminated ore and shale-like, ferruginous matrix. Braunite is the dominant ore phase either as fine, crystalline laminations or as coarser crystalline masses. Hematite is also present, occurring in the textural form of specularite (50 to $100 \mu \mathrm{m})$. The distribution of $\mathrm{Fe}, \mathrm{Mn}, \mathrm{Si}, \mathrm{Ba}, \mathrm{Na}$ and $\mathrm{Al}$ in a typical sample from the ferromanganese ore was determined by EPMA element mapping (see Supplementary Materials). The bulk of the Mn is concentrated within braunite-rich clasts, whereas the shale matrix contains little to no Mn. This is in 
stark contrast to the $\mathrm{Al}$ distribution which is almost exclusively concentrated in the shale-like matrix, though braunite does tend to contain some aluminium. Sodium is also present in the matrix, albeit in lower concentrations. The matrix is also Si-rich relative to braunite.

Barium is predominantly present as banalsite, named after its composition: $\mathrm{BaNa}_{2} \mathrm{Al}_{4} \mathrm{Si}_{4} \mathrm{O}_{16}$ [37]. It was first found in veins cross-cutting tephroite-rich manganese ore in Wales [37]. It is more commonly found in conjunction with its Sr end-member (stronalsite) in alkaline igneous rocks such as the Pilansberg peralkaline complex in South Africa [38]. Banalsite has also been described from metamorphosed bedded manganese ores in Japan [39].

Banalsite is present as fine-grained aggregates in vugs and veinlets throughout the ore. Bulk rock XRD analysis of one sample from the ferromanganese ore of SLT-017 revealed a multiphase spectrum. The two dominant phases are hematite and braunite but banalsite is also detectable. Other XRD analyses taken across the orebody reveal similar spectra, with the main difference between samples being the varying proportions of hematite to braunite.

\section{Geochemistry}

This section provides bulk rock geochemical data from selected samples from drill cores SLT-015, SLT-017, and includes also data from manganiferous breccia of drill core AKH-49 previously studied for its alkali mineralogy by Moore et al. [13]. All data are included in Table 5.

Table 5. Bulk rock major (wt. \%) and trace element (ppm) concentrations for selected matrix samples in drill cores SLT-015, SLT-017 and AKH-49.

\begin{tabular}{|c|c|c|c|c|c|c|c|c|c|c|c|c|}
\hline \multirow{2}{*}{$\begin{array}{c}\text { Drill Core } \\
(\mathrm{mbs})\end{array}$} & \multicolumn{3}{|c|}{ SLT-015: Shale Matrix } & \multicolumn{3}{|c|}{ SLT-015: Fe-Mn Matrix } & \multicolumn{3}{|c|}{ SLT-017 } & \multicolumn{3}{|c|}{ AKH-49 } \\
\hline & 80.4 & 85.5 & 87.5 & 80.7 & 88.7 & 90 & 91.5 & 93.4 & 93.8 & 194.9 & 195.2 & 198 \\
\hline $\mathrm{SiO}_{2}$ & 36.2 & 33.1 & 36.5 & 7.5 & 5.07 & 3.2 & 7.31 & 15.4 & 10.2 & 49.5 & 59.8 & 66.3 \\
\hline $\mathrm{TiO}_{2}$ & 1.18 & 1.33 & 1.35 & 0.16 & 0.16 & 0.06 & 0.10 & 0.63 & 0.13 & 0.35 & 0.71 & 0.68 \\
\hline $\mathrm{Al}_{2} \mathrm{O}_{3}$ & 34.1 & 27.5 & 27.4 & 4.95 & 3.18 & 0.97 & 3.23 & 12.9 & 7.04 & 8.97 & 14.4 & 12.3 \\
\hline $\mathrm{Fe}_{2} \mathrm{O}_{3}$ & 12.3 & 25.5 & 17.5 & 19.8 & 37.0 & 61.6 & 30.5 & 21.8 & 20.8 & 19.8 & 10.5 & 10.3 \\
\hline $\mathrm{MnO}$ & 1.03 & 1.16 & 5.40 & 60.4 & 43.9 & 31.0 & 50.4 & 35.4 & 49.4 & 12.1 & 1.54 & 0.94 \\
\hline $\mathrm{MgO}$ & 0.29 & 0.17 & 0.30 & 0.08 & 0.25 & 0.08 & 0.08 & 0.46 & 0.17 & 1.09 & 0.73 & 0.73 \\
\hline $\mathrm{CaO}$ & 0.47 & 0.15 & 0.25 & 2.31 & 0.63 & 0.59 & 1.58 & 0.81 & 3.16 & 0.51 & 0.11 & 0.11 \\
\hline $\mathrm{Na}_{2} \mathrm{O}$ & 4.24 & 3.76 & 3.98 & 0.14 & 0.37 & 0.08 & 0.39 & 2.00 & 1.07 & 4.63 & 0.69 & 0.62 \\
\hline $\mathrm{K}_{2} \mathrm{O}$ & 1.41 & 1.60 & 2.06 & 0.03 & 1.72 & 0.03 & 0.11 & 0.44 & 0.10 & 0.70 & 3.85 & 4.29 \\
\hline $\mathrm{P}_{2} \mathrm{O}_{5}$ & 0.15 & 0.04 & 0.13 & 0.20 & 0.18 & 0.14 & 0.87 & 0.09 & 0.39 & 0.03 & 0.05 & 0.06 \\
\hline $\mathrm{BaO}$ & 1.13 & 0.15 & 0.11 & 2.66 & 2.60 & 0.51 & 2.48 & 5.12 & 3.10 & 0.44 & 4.29 & 1.45 \\
\hline LOI & 5.77 & 4.72 & 4.71 & 1.95 & 4.12 & 0.92 & 0.80 & 2.40 & 2.64 & 0.64 & 2.33 & 1.95 \\
\hline $\mathrm{H}_{2} \mathrm{O}^{-}$ & 0.94 & 0.53 & 0.50 & 0.24 & 0.31 & 0.24 & 0.22 & 0.45 & 0.24 & 0.26 & 0.38 & 0.41 \\
\hline Total & 99.1 & 99.8 & 100.2 & 100.4 & 99.5 & 99.4 & 98.1 & 97.9 & 98.3 & 99.0 & 99.3 & 100.2 \\
\hline $\mathrm{Zn}$ & 50 & 23 & 31 & 153 & 100 & 66 & 62 & 61 & 65 & 74 & 44 & 2 \\
\hline $\mathrm{Cu}$ & 68 & 61 & 142 & 1504 & 271 & 235 & 311 & 177 & 95 & 53 & 28 & 7 \\
\hline $\mathrm{Ni}$ & 123 & 86 & 273 & 198 & 153 & 213 & 20 & 105 & 25 & 1371 & 295 & 13 \\
\hline Co & 47 & 32 & 19 & 54 & 13 & 16 & 16 & 28 & 7 & 91 & 50 & 59 \\
\hline $\mathrm{Cr}$ & 160 & 1068 & 108 & 109 & 141 & 101 & 113 & 124 & 118 & 82 & 48 & 55 \\
\hline $\mathrm{V}$ & 34 & 253 & 111 & 160 & 137 & 144 & 174 & 27 & 78 & 21 & $<4$ & 5 \\
\hline Sc & 40 & 66 & 21 & 51 & 11 & 6 & 12 & 29 & 8 & 19 & 10 & 13 \\
\hline Th & 33 & 7 & 32 & $<6$ & 14 & $<6$ & 15 & 47 & 19 & 15 & 23 & 21 \\
\hline $\mathrm{Pb}$ & 35 & 78 & 45 & 251 & 1003 & 387 & 968 & 2255 & 1202 & 590 & 885 & 576 \\
\hline $\mathrm{Rb}$ & 56 & 51 & 63 & $<2$ & 33 & $<3$ & 3 & 16 & 2 & 13 & 96 & 117 \\
\hline Mo & $<1$ & $<1$ & $<1$ & $<2$ & $<2$ & 3 & $<2$ & $<2$ & $<2$ & 1 & $<1$ & $<1$ \\
\hline $\mathrm{Nb}$ & 22 & 8 & 26 & 3 & $<2$ & $<2$ & 2 & 12 & 2 & 7 & 14 & 15 \\
\hline $\mathrm{Zr}$ & 233 & 140 & 571 & 46 & 34 & 16 & 21 & 245 & 23 & 100 & 284 & 258 \\
\hline $\mathrm{Y}$ & 40 & 16 & 59 & 19 & 24 & 30 & 18 & 30 & 9 & 107 & 105 & 76 \\
\hline $\mathrm{U}$ & $<2$ & $<2$ & $<2$ & $<4$ & $<5$ & $<5$ & $<4$ & 5 & $<3$ & $<3$ & $<2$ & $<2$ \\
\hline $\mathrm{Sr}$ & 501 & 101 & 71 & 488 & 2165 & 377 & 1463 & 947 & 1700 & 94 & 181 & 84 \\
\hline
\end{tabular}

\subsection{Bulk Rock Major and Trace Elements}

Two broad types of matrix are recognised in core SLT-015: the shale matrix contains high percentages of $\mathrm{SiO}_{2}$ (33.1-36.5 wt. \%), $\mathrm{Al}_{2} \mathrm{O}_{3}$ (27.4-34.1 wt. \%) and $\mathrm{Fe}_{2} \mathrm{O}_{3}$ (17.5-25.5 wt. \%). The $\mathrm{SiO}_{2}$ and $\mathrm{Al}_{2} \mathrm{O}_{3}$ as well as the presence of more than $1 \mathrm{wt} . \% \mathrm{TiO}_{2}$ in the shale matrix is indicative of a 
detrital derivation. A substantial amount of $\mathrm{Na}_{2} \mathrm{O}$ is also present, ranging from 3.7 to 4.2 wt. \% with lesser $\mathrm{K}_{2} \mathrm{O}$ (1.4-2.1 wt. \%). The Fe-Mn matrix is dominated by $\mathrm{Fe}_{2} \mathrm{O}_{3}$ (19.8-61.6 wt. \%) and $\mathrm{MnO}$ (31.0-60.4 wt. \%) and much less $\mathrm{SiO}_{2}(<10 \mathrm{wt}$. \%). The ferromanganese ore of SLT-017 predominantly consists of $\mathrm{Fe}_{2} \mathrm{O}_{3}\left(20.8-30.5\right.$ wt. \%) and $\mathrm{MnO}\left(31.0-60.4\right.$ wt. \%) with lesser $\mathrm{SiO}_{2}(7.3-15.4$ wt. \%) and $\mathrm{Al}_{2} \mathrm{O}_{3}(1.0-4.95$ wt. \%).

The most abundant component in the matrix of drill core $\mathrm{AKH}-49$ is $\mathrm{SiO}_{2}(49.5-66.3 \mathrm{wt}$. \%), consistent with corresponding XRD spectra. $\mathrm{Al}_{2} \mathrm{O}_{3}$ concentrations range between 9.0 and $14.4 \mathrm{wt}$. $\%$ and $\mathrm{Fe}_{2} \mathrm{O}_{3}$ concentrations range between 10.3 and $19.8 \mathrm{wt}$ \%. MnO concentrations have a large range from 0.9 to $12.1 \mathrm{wt}$. \%. A common feature in all samples is the unusually elevated $\mathrm{BaO}$ concentrations which, for the majority of samples, have concentration greater than 1 wt. \%. SLT-017 samples show particularly elevated $\mathrm{BaO}$ concentrations, with one sample as high as $5.1 \mathrm{wt}$. \%. These high concentrations of $\mathrm{BaO}$ in SLT-017 can be tentatively attributed to the presence of banalsite in the ore. This coincides with bulk $\mathrm{Na}_{2} \mathrm{O}$ concentrations up to $2 \mathrm{wt}$ \%.

Lead concentrations in SLT-17 (968-2255 ppm) and AKH-49 (576-885 ppm) are elevated relative to SLT-015 samples (35-387 ppm, with one sample at $1003 \mathrm{ppm})$. Strontium concentrations are elevated in SLT-017 (947-1700 ppm) and in the ferromanganiferous samples of SLT-015 (377-2165 ppm) relative to the shale matrix of SLT-015 (71-501 ppm) and AKH-49 (84-181 ppm). With the exception of four trace element concentrations ( $\mathrm{Cu}$ in sample 15-03, $\mathrm{Ni}$ in sample 49-1, $\mathrm{Cr}$ in sample 15-09 and $\mathrm{Zr}$ in sample 15-11B; see Table 5), no other trace element data concentrations exceed 300 ppm. Uranium and molybdenum concentrations are mostly below the detection limit.

\section{2. ${ }^{40}$ Ar ${ }^{39}$ Ar Dating of Potassium Feldspar}

Adularia from drill core SLT-015 were dated by ${ }^{40} \mathrm{Ar} /{ }^{39} \mathrm{Ar}$ in situ ultraviolet laser ablation. Compositional maps were taken of the analysed sample (Figure 8). However, due to persisting radioactivity in the ablated sample, the opposite face was used for compositional mapping. Nineteen spot analyses yielded ages between $681.1 \pm 3.2 \mathrm{Ma}$ and $517.4 \pm 5.0 \mathrm{Ma}$ with a median of $627.7 \mathrm{Ma}$ (Inter-quartile range: 570.9-650.5 Ma). The probability density distribution curve (Figure 9) was made by summing up all the normal distribution curves made from each age datum. The curve shows two main age groups with means of $648 \pm 20 \mathrm{Ma}(n=12)$ and $557 \pm 27 \mathrm{Ma}(n=7)$.

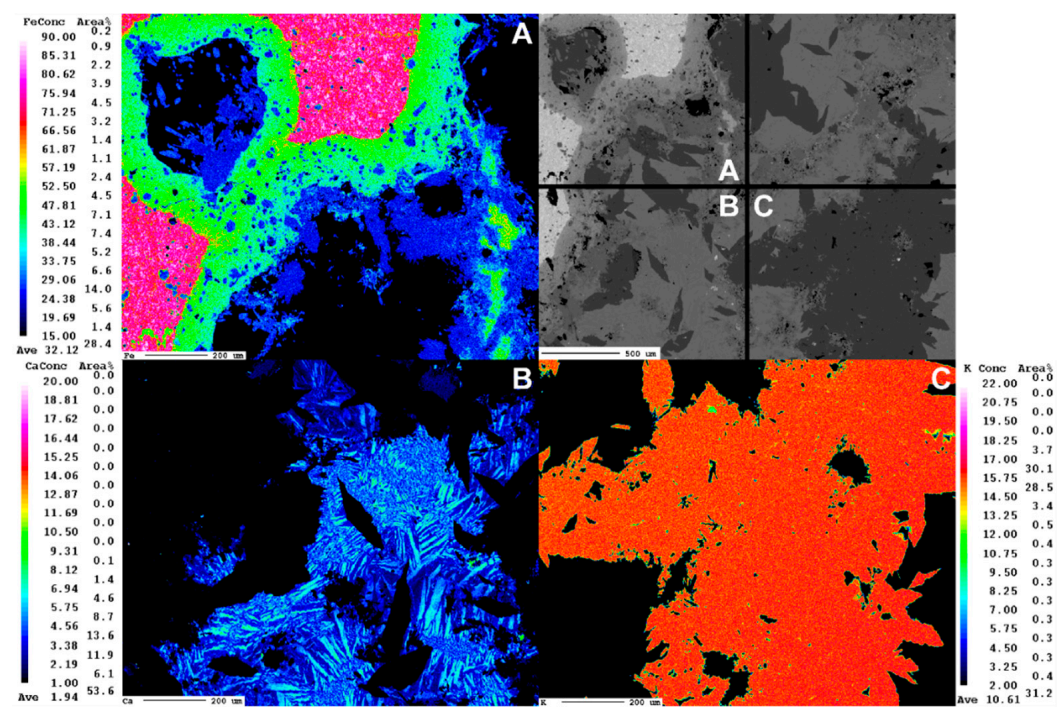

Figure 8. Compositional maps from the counterpart of the sample used for ${ }^{40} \mathrm{Ar} /{ }^{39} \mathrm{Ar}$ dating. The backscatter electron image in the top right of the figure shows the entire mapped area-dark grey areas effectively highlight microcline distribution. A. Fe concentrations in the matrix and vug margins showing zonation of Fe from high concentration at the boundary to low concentration in the centre-the mineral represented by ca. $25 \% \mathrm{Fe}$ (blue) is aegirine. B. Ca concentrations reveal the intergrowth of varying compositions of the sérandite-pectolite series. C. K concentrations are confined to microcline. 


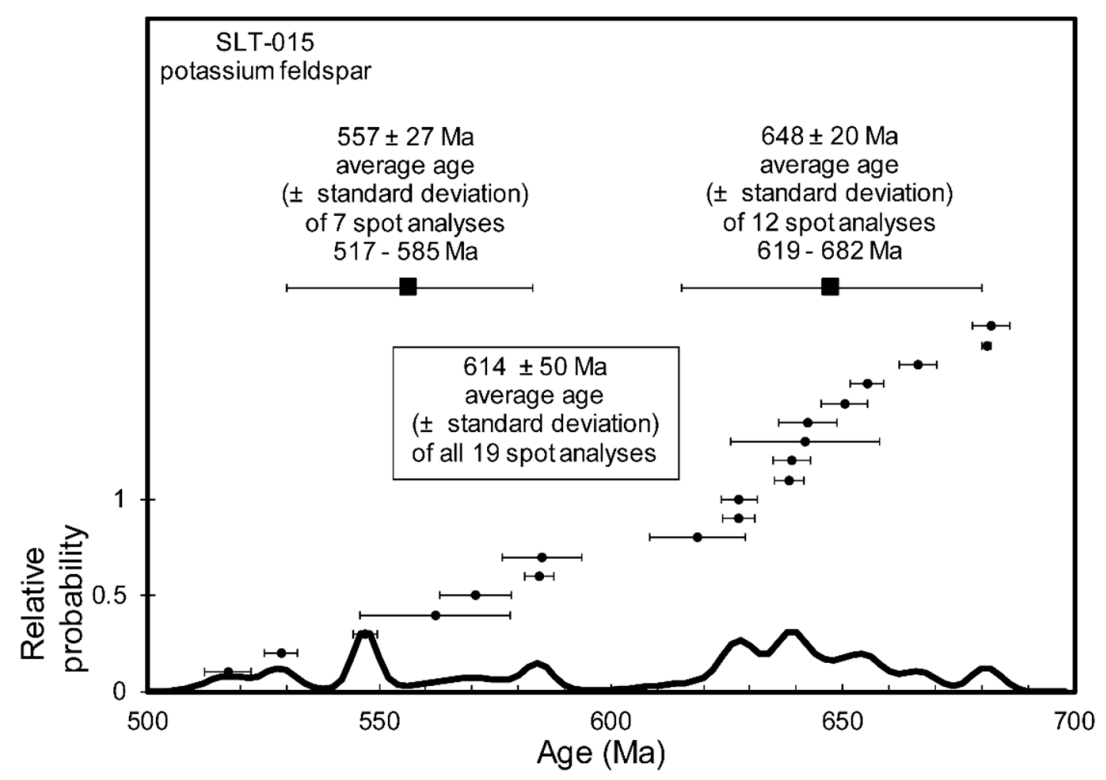

Figure 9. Distribution of all ${ }^{40} \mathrm{Ar} /{ }^{39} \mathrm{Ar}$ age ata obtained in this study from vug-filling potassium feldspar in drill core SLT-015. The probability density distribution curve (continuous bold line) sums all the normal distribution for each age datum.

\section{Discussion}

The prevailing models for the development of manganese ores in the PMF invoke residual karst-forming processes in manganese-rich dolomites of the Campbellrand Subgroup [1,9]. The models proposed by Plehwe-Leisen and Klemm [9] and Gutzmer and Beukes [1] differ for each of the two main types of deposits (i.e., siliceous and ferruginous). Gutzmer and Beukes [1] consider the siliceous ores to have formed in karstic systems developed beneath the Asbestos Hills BIFs. Plehwe-Leisen and Klemm [9], however, regard the start of karstification to have occurred before the onset of Asbestos Hills deposition. In terms of the nature of fluids involved in this system, Plehwe-Leisen and Klemm [9] suggest a descending meteoric fluid which evolves through the orebody as it descends, increasing in $\mathrm{pH}$ and decreasing in Eh. This develops an alkaline environment at the base of the karstic depression [9]. Gutzmer and Beukes [1] consider barian muscovite, aegirine and albite, which are present in the siliceous ores, to be of metamorphic origin, whereas the reported presence of romanechite and cryptomelane would have resulted from the replacement of braunite under supergene conditions [1]. Both sets of authors thus pay little attention to the potential influence of hydrothermal fluids on ore formation and Mn-enrichment.

\subsection{Evidence for Hydrothermal Mineral Formation}

The main Na-bearing phases in the studied drill cores are aegirine, albite, armbrusterite, sugilite and minerals of the sérandite-pectolite series (particularly the sérandite end-member). The blocky, euhedral nature of most of the albite in SLT-015 and AKH-49 suggests that it was deposited hydrothermally in open space. Inclusion of sérandite in some albite grains may suggest crystallization of albite after sérandite. It is unlikely that any albite is detrital as there is no evidence of albite-bearing lithic fragments; albite instead occurs either in masses of euhedral grains in vugs, lining vug walls, or as individual euhedral grains. The lack of rounding in individual grains would further support authigenic formation.

Aegirine in parts of core SLT-015 occurs in abundance as laths growing outward from the walls of small vugs. Analysis of the enveloping matrix, in combination with average hematite and aegirine analyses, allow for crude estimations of the maximum modal abundance of aegirine. Assuming that most-if not all —of the contained $\mathrm{SiO}_{2}$ is assigned to aegirine, a modal abundance of up to $68 \%$ aegirine and 30\% hematite can be calculated for the matrix in this instance. Members of the 
sérandite-pectolite series are also omnipresent throughout drill cores SLT-015 and AKH-49, with the Mn end-member sérandite being most abundant. Texturally, they tend to occur as radial aggregations and less commonly as laths, either as vug fills but also as pseudomorphic replacements after quartz.

Natrolite also occurs in parts of drill core SLT-015, either as fine-grained rims on the walls of vugs in association with albite \pm sérandite \pm quartz, or completely filling smaller vugs. One possible explanation for the presence of natrolite in the manganese ore is the alteration of albite in the presence of water as given in the following equation:

\section{Albite $+\mathrm{H}_{2} \mathrm{O} \leftrightarrow$ Natrolite +3 Quartz}

Textural evidence, however, shows no quartz where natrolite is associated with albite, while some vugs are completely filled by natrolite only. Gutzmer and Beukes [1] point to the existence of diaspore in shale lenses in the ferruginous ores of the Western Belt. If it is assumed that diaspore was present at the time of influx of a Na-rich fluid, it follows that both natrolite and albite can be deposited in vugs according to the equation:

$$
\text { 3Diaspore }+6 \text { Quartz }+3 \mathrm{NaOH}_{\mathrm{aq}} \leftrightarrow \text { Albite }+ \text { Natrolite }+2 \mathrm{H}_{2} \mathrm{O}
$$

The latter scenario better explains the textures observed in drill core SLT-015.

In addition to Na-rich phases, drill core AKH-49 contains vug-filling phases that are Na- and K-bearing such as armbrusterite and sugilite, as well as some microcline and norrishite. In drill core SLT-015, however, the dominant potassic phase is microcline. This is most likely a function of the availability of $\mathrm{Li}$ in the fluid at the time of deposition, and possibly the level of silica concentration as well. Microcline in SLT-015 has an adularia-like habit, typical of potassium feldspars crystallizing from low-temperature hydrothermal solutions such as those typifying epithermal systems in volcanic arc environments [34].

$\mathrm{Ca}-, \mathrm{Ba}-$ and $\mathrm{CO}_{2}$-rich phases are also present in the examined assemblages. Coarse-grained calcite occurs as the core of some vugs in drill core SLT-015. Minor piemontite is also present lining the walls of small quartz-bearing vugs. A number of barium species exist in these rocks, particularly in drill cores SLT-015 and AKH-49. Witherite is the most abundant barium phase, commonly occurring as coarse, euhedral grains. Barite is also present but its abundance is variable and generally low. Instead, barium silicates such as noélbensonite and banalsite seem to prevail. The abundance of banalsite in SLT-017 can account for almost all of the barium present in these rocks. An approximation of modal abundance using one of the bulk rock major element analyses from drill core SLT-017 gives modal compositions of $30 \%$ hematite, $26 \%$ banalsite, $22 \%$ braunite, $12 \%$ paragonite and $4 \%$ diaspore; this leaves $6 \%$ unaccounted for with small amounts of each oxide remaining.

Noélbensonite is found in drill core SLT-015 and is the first occurrence recorded in Africa, as previously reported by Costin et al. [29]. Replacement textures of microcline by noélbensonite and sérandite by witherite, As-rich tokyoite and noélbensonite, are suggestive of late deposition of barium in a hydrothermal system. At the Woods mine, Australia, the type locality of noélbensonite, this mineral replaces sérandite amongst other Mn-bearing minerals [40]. Kawachi et al. [40] interpret such replacement as a result of the activity of relatively low-temperature Ba-bearing fluids that infiltrated after the metamorphic thermal maximum that produced sérandite. However, Armbruster et al. [41] report hennomartinite, a structural relative of noélbensonite, at Wessels mine, South Africa, where the mineral precipitated in veins cogenetically with sérandite-pectolite and sugilite.

The discovery of As-rich tokyoite is the first occurrence of the brackebuschite group minerals that contains both arsenic and vanadium [29]. Tokyoite proper is the Mn-analogue of gamagarite [42] which was first described in the Postmasburg manganese field by De Villiers [43]. De Villiers [43] linked the gamagarite to fluid activity but made no comment on the source of such a fluid. Nevertheless, the discovery of As-rich tokyoite to the south of the original gamagarite locality seems to indicate the regional activity of a $\mathrm{V}-$, Ba-, and As-bearing fluid. 
All of these minerals show textural evidence of hydrothermal processes either through the habit of the mineral itself (e.g., microcline adularia and vug-filling euhedral albite) or by exhibiting apparent replacement relationships with other minerals (e.g., noélbensonite after microcline and sérandite). Furthermore, the presence of zoned vugs can best be explained by successive precipitation effects during hydrothermal processes. Given the above, it would appear that the hydrothermal fluid affecting the ore deposits of the PMF was rich in barium, sodium, potassium and calcium, and also contained at least lithium, vanadium and arsenic as lesser constituents.

Arguably the most notable feature of the mineralogical and textural results described in the foregoing is the virtually complete absence of common, supergene-related $\mathrm{Mn}$ - and Fe-minerals such as romanechite, cryptomelane, pyrolusite, lithiophorite, ramsdellite and goethite, some of which have previously been described as part of the mineral assemblage of siliceous ores of the PMF [1]. The absence of a typical supergene mineral assemblage in the drill cores of the present study indicates that either: (i) supergene processes were not operative in producing the studied ores; or (ii) postulated supergene assemblages have been completely obliterated by subsequent hydrothermal re-constitution. It also raises the possibility that previously observed supergene Mn minerals may be genetically linked to younger supergene events that actually overprint the hydrothermal assemblages reported here and in other similar studies [13,29]. It therefore remains open whether the PMF deposits are true ancient-supergene ores, hydrothermally modified supergene ores, or largely hydrothermal ores that are variably overprinted by supergene processes.

\subsection{Timing and Spatial Scale of Hydrothermal Fluid Migration}

While common minerals in all examined drill cores are braunite and hematite, a striking similarity also exists between other less common elements present in the observed mineral assemblages (Table 6), namely $\mathrm{Na}, \mathrm{Ba}, \mathrm{K}, \mathrm{Si}, \mathrm{Fe}, \mathrm{Mn}$ and $\mathrm{Al}$. Most common mineral hosts are $\mathrm{Na}$ - and $\mathrm{K}$-bearing silicates and less so carbonates, oxides and sulphates.

Table 6. Comparative table of mineral assemblages in manganese deposits of the PMF and Kalahari Manganese Field (KMF) as well as near the Bruce iron ore mine.

\begin{tabular}{|c|c|c|c|c|c|}
\hline Name & Formula & AKH-49 ${ }^{1}$ & SLT-015 & SLT-017 & $\mathrm{KMF}^{2}$ \\
\hline Aegirine & $\mathrm{NaFe}^{3+} \mathrm{Si}_{2} \mathrm{O}_{6}$ & $X$ & $X$ & & $X$ \\
\hline Aegirine-augite & & & $x$ & & \\
\hline Albite & $\mathrm{NaAlSi}_{3} \mathrm{O}_{8}$ & $X$ & $x$ & & $x$ \\
\hline Armbrusterite & $\mathrm{Na}_{6} \mathrm{~K}_{5} \mathrm{Mn}^{3+} \mathrm{Mn}^{2+}{ }_{14}\left[\mathrm{Si}_{9} \mathrm{O}_{22}\right]_{4}(\mathrm{OH})_{10} \cdot 4 \mathrm{H}_{2} \mathrm{O}$ & $x$ & & & \\
\hline Banalsite & $\mathrm{BaNa}_{2} \mathrm{Al}_{4} \mathrm{Si}_{4} \mathrm{O}_{16}$ & & & $x$ & $x$ \\
\hline Barite & $\mathrm{BaSO}_{4}$ & & $X$ & & $x$ \\
\hline Barytocalcite & $\mathrm{BaCa}\left(\mathrm{CO}_{3}\right)_{2}$ & & $x$ & & \\
\hline Braunite & $\mathrm{Mn}^{2+} \mathrm{Mn}^{3+}{ }_{6} \mathrm{O}_{8} \mathrm{SiO}_{4}$ & $X$ & $x$ & $x$ & $X$ \\
\hline Calcite & $\mathrm{CaCO}_{3}$ & & $x$ & & $x$ \\
\hline Hematite & $\mathrm{Fe}_{2} \mathrm{O}_{3}$ & $x$ & $x$ & $x$ & $x$ \\
\hline Hollandite & $\mathrm{Ba}\left(\mathrm{Mn}^{4+}, \mathrm{Mn}^{3+}\right)_{8} \mathrm{O}_{16}$ & & $x$ & & $x$ \\
\hline K-feldspar & $\mathrm{KAlSi}_{3} \mathrm{O}_{8}$ & $X$ & $x$ & & \\
\hline Kentrolite & $\mathrm{Pb}_{2} \mathrm{Mn}^{3+}{ }_{2} \mathrm{O}_{2}\left(\mathrm{Si}_{2} \mathrm{O}_{7}\right)$ & $x$ & & & $x$ \\
\hline Natrolite & $\mathrm{Na}_{2} \mathrm{Al}_{2} \mathrm{Si}_{3} \mathrm{O}_{10} \cdot \mathrm{H}_{2} \mathrm{O}$ & & $X$ & & $x$ \\
\hline Noelbensonite & $\mathrm{BaMn}^{3+}{ }_{2} \mathrm{Si}_{2} \mathrm{O}_{7}(\mathrm{OH})_{2} \cdot \mathrm{H}_{2} \mathrm{O}$ & & $x$ & & \\
\hline Norrishite & $\mathrm{KLiMn}^{3+}{ }_{2} \mathrm{Si}_{4} \mathrm{O}_{12}$ & $x$ & & & \\
\hline Paragonite & $\mathrm{NaAl}_{2}\left(\mathrm{Si}_{3} \mathrm{Al}\right) \mathrm{O}_{10}(\mathrm{OH})_{2}$ & & $x$ & $X$ & \\
\hline Partridgeite & $\mathrm{Mn}_{2} \mathrm{O}_{3}$ & & $x$ & & $x$ \\
\hline Pectolite & $\mathrm{NaCa}_{2} \mathrm{Si}_{3} \mathrm{O}_{8}(\mathrm{OH})$ & $x$ & $x$ & & $x$ \\
\hline Piemontite & $\mathrm{Ca}_{2}\left(\mathrm{Al}, \mathrm{Mn}^{3+}, \mathrm{Fe}^{3+}\right)_{3}\left(\mathrm{SiO}_{4}\right)\left(\mathrm{Si}_{2} \mathrm{O}_{7}\right) \mathrm{O}(\mathrm{OH})$ & & $x$ & & $x$ \\
\hline Quartz & $\mathrm{SiO}_{2}$ & $X$ & $x$ & & $x$ \\
\hline Serandite & $\mathrm{NaMn}^{2+}{ }_{2} \mathrm{Si}_{3} \mathrm{O}_{8}(\mathrm{OH})$ & $x$ & $x$ & & $x$ \\
\hline Sericite & & $x$ & & & \\
\hline Strontianite & $\mathrm{SrCO}_{3}$ & $x$ & $x$ & & \\
\hline Sugilite & $\mathrm{KNa}_{2}\left(\mathrm{Fe}^{3+}{ }_{,} \mathrm{Mn}^{3+} \mathrm{Al}\right)_{2} \mathrm{Li}_{3} \mathrm{Si}_{12} \mathrm{O}_{30}$ & $x$ & & & $x$ \\
\hline Tokyoite & $\mathrm{Ba}_{2} \mathrm{Mn}^{3+}\left[(\mathrm{As}, \mathrm{V}) \mathrm{O}_{4}\right]_{2}(\mathrm{OH})$ & & $x$ & & \\
\hline Witherite & $\mathrm{BaCO}_{3}$ & $x$ & $x$ & & \\
\hline
\end{tabular}

${ }^{1}$ Moore et al. [13] and this study. ${ }^{2}$ Gutzmer and Beukes [34]. 
Aegirine was previously reported in the PMF by De Villiers [44] in association with albite. Aegirine is also reported from the Hotazel Formation by Tsikos and Moore [45]. These authors postulate that aegirine resulted from sodic metasomatism of BIF of the Hotazel Formation by late hydrothermal fluid-flow involving sodic brines. Cairncross et al. [46] also describe prehnite occurring in association with hydroxyl-apophyllite, datolite, inesite, calcite and pectolite from the $\mathrm{N}^{\prime} \mathrm{Chwaning}$ mine in the KMF. Although no prehnite has been found in this study, the occurrence of natrolite is significant as it is commonly associated with prehnite [33,45]. Cairncross et al. [46] suggest that the occurrence of prehnite in the Wessels-type, high-grade manganese ores of the $\mathrm{N}^{\prime} \mathrm{Chwaning}$ mine is potentially indicative of a hydrothermal overprint by low temperature fluids $\left(<250^{\circ} \mathrm{C}\right)$.

We contend that the abundance of sodium-bearing phases such as aegirine, albite, banalsite, natrolite and sérandite-pectolite in the study rocks and throughout the PMF, and the presence of strikingly similar assemblages in the KMF, are not circumstantial localised occurrences but originate from a common episode of regional-scale fluid-flow as suggested by Moore et al. [13]. Identifying the conduit/s for such a regional flow remains challenging; however, the Blackridge thrust fault system and the unconformity between the Transvaal and Olifantshoek Supergroups, are both viable candidates.

A number of large-scale tectonic events have affected the margins of the Kaapvaal Craton. The oldest is thought to be that of the Kheis orogeny at around $1800 \mathrm{Ma}$, followed by the Namaqua orogeny which took place between 1100 and $1050 \mathrm{Ma}$ [26]. Younger events associated with the amalgamation of Gondwana in the Neoproterozoic are represented regionally by the pan-African orogeny as exemplified by the Damara Mobile Belt.

A number of geochronological studies on alteration minerals from the PMF and KMF, have produced mixed results. Dixon [33] dated sugilite from Wessels mine in the KMF which yielded a $\mathrm{Rb}-\mathrm{Sr}$ age of $1350 \pm 269 \mathrm{Ma}$ and a Pb-Pb age of $1270 \pm 30 \mathrm{Ma}$. Gnos et al. [47] also dated sugilite from Wessels mine using the ${ }^{40} \mathrm{Ar} /{ }^{39} \mathrm{Ar}$ technique which yielded an age of 1048.1 $\pm 5.9 \mathrm{Ma}$. Norrishite from Wessels mine was also dated by Gnos et al. [47] but the results were inconclusive and consequently interpreted in terms of two events: one at around $1010 \mathrm{Ma}$, representing the crystallization age of norrishite, and another, at approximately $850 \mathrm{Ma}$, recording an alteration overprint.

Moore et al. [13] dated sugilite from the Bruce mine in the northern part of the PMF using the ${ }^{40} \mathrm{Ar} /{ }^{39} \mathrm{Ar}$ technique. This yielded an age of $620.2 \pm 3.3 \mathrm{Ma}$ but these authors pointed to a lack of confidence in the age as a result of thermal overprinting causing a loss of radiogenic ${ }^{40} \mathrm{Ar}$. More recent geochronological work has brought renewed significance to a possible fluid event during late Neoproterozoic times. Fairey et al. [25], in an attempt to date un-dolomitised carbonate rocks of the Mooidraai Formation in the upper part of the Transvaal Supergroup, found that four discordant points formed a discordia line that yields a lower intercept age of $590 \pm 63 \mathrm{Ma}$. Gumsley et al. [21] also dated zircon and baddeleyite crystals from the Ongeluk volcanics and genetically related intrusions across the Transvaal Supergroup, which yielded lower intercept ages (with the exception of one sample) indicative of late Neoproterozoic isotopic disturbance. To this end, the late Neoproterozoic ages of hydrothermal potassium feldspars from this study add increasing credence to the hypothesis by Moore et al. [13] for a regional hydrothermal event having affected both the PMF and KMF around that time. The timing of such hydrothermal activity is broadly coincident with the pan-African orogeny associated with the amalgamation of Gondwana-a trans-crustal tectonic event that may have played a role in creating thermal gradients for large-scale fluid migration.

\subsection{Mechanisms and Effects of Fluid Metasomatism}

Any metasomatic processes involving the influx of fluid through rock is a chemically complex process that requires consideration of the mineralogy and chemistry of the parent rock and the chemistry of the infiltrating fluid. Geochemical analyses presented earlier show that, in most cases, aluminium and, to a large extent, silicon in the studied ores have a detrital origin. Dove and Nix [48] showed experimentally that the ability of an aqueous fluid to dissolve quartz is enhanced through the addition of $\mathrm{Mg}^{2+}, \mathrm{Ca}^{+}, \mathrm{Na}^{+}, \mathrm{K}^{+}$and particularly $\mathrm{Ba}^{2+}$. Their experiments provide an elegant means 
to construct a model for the formation of gangue assemblages associated with the PMF ores. These experiments were conducted at $200{ }^{\circ} \mathrm{C}$, a temperature that is probably similar to that of the fluid which affected the PMF ores (e.g., [10]). According to the experiments conducted by Dove and Nix [48], it is possible that metals such as $\mathrm{Ba}, \mathrm{Na}$ and $\mathrm{K}$ were mainly carried as chloride salt solutions and possibly as hydroxyl complexes as well. The oxidized, high-pH carrier fluid interacted with quartz/chert clasts in the residual Wolhaarkop breccia thus bringing $\mathrm{SiO}_{2}$ into solution. During this process, it is also likely that manganese and iron were mobilized at least on a local scale. At some point during quartz dissolution, the fluid became supersaturated in silica and lost its transporting capacity. The mode of crystalline $\mathrm{SiO}_{2}$ in the rock would have determined the shape of the vug that would develop: if the fluid dissolved fine-grained chert, then the vugs would be irregular in shape; if, however, polygonal coarser-grained quartz was dissolved, then the vug would have an inherited shape and it would appear as though minerals within them were pseudomorphically replacing quartz crystals.

The solubility of $\mathrm{BaCl}_{2}, \mathrm{NaCl}$ and $\mathrm{KCl}$ in water increases linearly with increasing temperature (Figure 10). $\mathrm{BaCl}_{2}$ and $\mathrm{KCl}$ behave similarly with $\mathrm{BaCl}_{2}$ being relatively more soluble than $\mathrm{KCl}$. In contrast, $\mathrm{NaCl}$ is much less soluble than the other two chlorides. Given these linear trends, it is unlikely that the solubility behaviour of these chlorides would change at elevated temperatures (ca. $150-200{ }^{\circ} \mathrm{C}$ ). One would also need to consider other factors such as composition, Eh and $\mathrm{pH}$ of the fluid in order to gain a complete understanding of the mechanisms of precipitation.

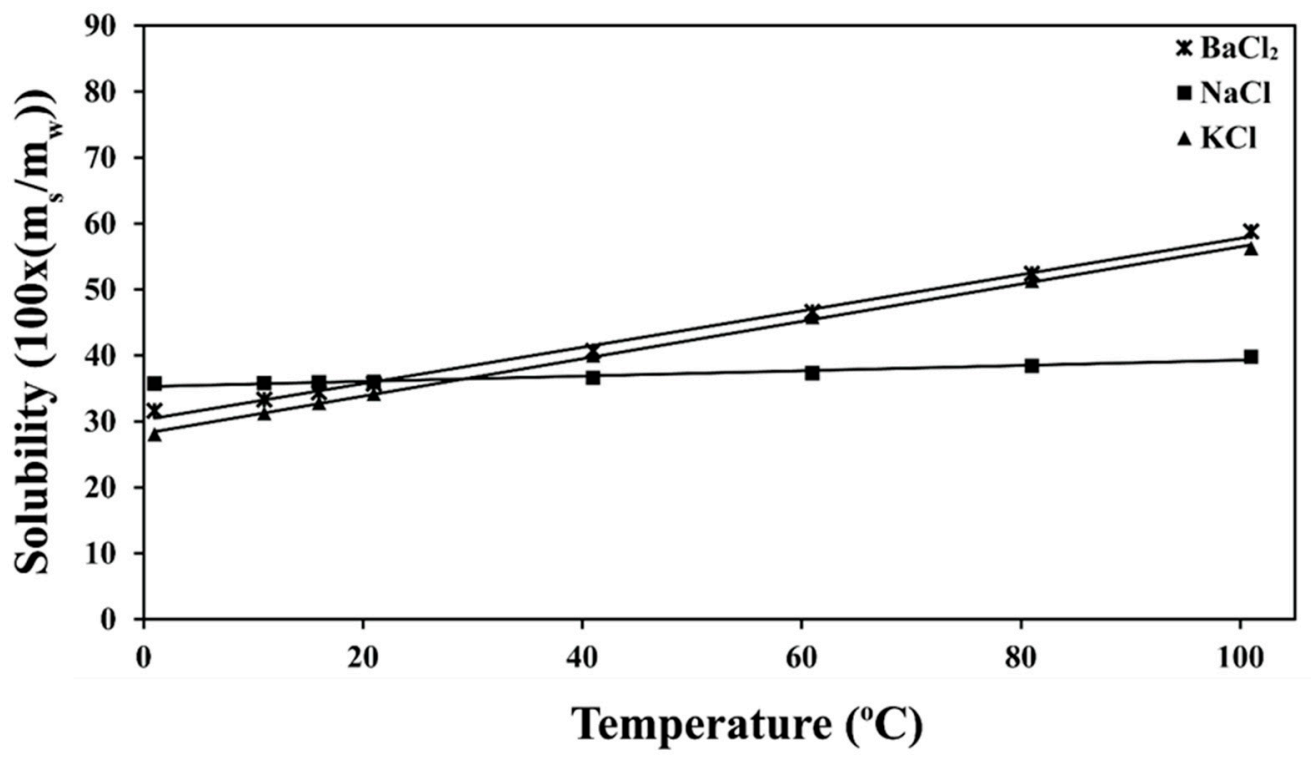

Figure 10. Solubility of $\mathrm{BaCl}_{2}, \mathrm{NaCl}, \mathrm{KCl}$ in water as a function of temperature (experimental data from [49]). Key: $\mathrm{m}_{\mathrm{s}}=$ mass of the solute; $\mathrm{m}_{\mathrm{w}}=$ mass of water.

Figure 11 illustrates the most likely paragenesis for the major mineral phases found in the ores of the PMF. Chert fragments are likely to have a detrital origin whereas polyhedral, authigenic quartz is probably of epigenetic origin as a result of recrystallization of chert, remobilization of silica and deposition in open spaces. Braunite and hematite formed during burial, low-grade metamorphism of initial, residual ferro-manganiferous wad. Given that $\mathrm{Na}$ is the least soluble of the major element constituents of the fluid, Na-rich minerals began to precipitate, reacting with available aluminium in the matrix to form Al-silicates such as albite and natrolite. Simultaneous reaction of the fluid with the surrounding ferro-manganiferous matrix allowed the precipitation of aegirine and sérandite, as these minerals were able to scavenge iron and manganese. The development of aegirine almost exclusively along vug walls supports such a hypothesis. Furthermore, where albite occurs in zoned vugs, it seemingly always occurs in the outermost zone along vug walls, indicating that it was one of the earliest minerals to be deposited. However, the occurrence of sérandite as inclusion in albite and 
natrolite suggests that sodic phases that contain manganese or iron were deposited before aluminous phases. Where natrolite is found replacing fractured quartz, it is likely that incomplete dissolution of the original coarse-grained quartz occurred.

\begin{tabular}{|c|c|c|c|c|}
\hline & Detrital & Diagenetic & $\begin{array}{l}\text { Low-grade } \\
\text { Metamorphic' }\end{array}$ & Hydrothermal \\
\hline \multicolumn{5}{|l|}{ Chert } \\
\hline \multicolumn{5}{|l|}{ Quartz } \\
\hline \multicolumn{5}{|l|}{ Braunite } \\
\hline \multicolumn{5}{|l|}{ Hematite } \\
\hline \multicolumn{5}{|l|}{ Partridgeite } \\
\hline \multicolumn{5}{|l|}{ Aegirine } \\
\hline \multirow{2}{*}{\multicolumn{5}{|c|}{ Aegirine-augite }} \\
\hline & & ' & ! & \\
\hline \multicolumn{5}{|l|}{ Serandite-pectolite } \\
\hline \multicolumn{5}{|l|}{ Albite } \\
\hline \multicolumn{5}{|l|}{ Natrolite } \\
\hline \multicolumn{5}{|l|}{ Microcline } \\
\hline \multirow{2}{*}{\multicolumn{5}{|c|}{ Sugilite }} \\
\hline & & & & \\
\hline \multicolumn{5}{|l|}{ Armbrusterite } \\
\hline \multicolumn{5}{|l|}{ Arsenotokyoite } \\
\hline \multicolumn{5}{|l|}{ Barite } \\
\hline \multicolumn{5}{|l|}{ Noelbensonite } \\
\hline \multirow{2}{*}{\multicolumn{5}{|c|}{ Witherite }} \\
\hline & & & & \\
\hline Calcite & & ! & ! & \\
\hline
\end{tabular}

Figure 11. Paragenetic chart of the major ore and gangue mineral constituents in the studied drill cores.

Potassium is the next least soluble species and would thus follow the deposition of sodium. The similarity in the solubility curves of $\mathrm{BaCl}_{2}$ and $\mathrm{KCl}$ suggests that $\mathrm{Ba}$ and $\mathrm{K}$ should precipitate largely congruently. It is also possible that the available reactants already present in the rock were more conducive for the formation of K-bearing phases than for Ba-bearing ones. The deposition of potassium is reflected in microcline in core SLT-015 which, like albite, tends to grow from the vug walls. However, the zonation of K-bearing phases is better seen in AKH-49 where masses of sugilite and/or armbrusterite occur in the inner core of zoned vugs [13]. The replacement of microcline and sérandite by Ba-bearing phases indicates that barium was the next element to precipitate out of solution. Therefore, minerals such as noélbensonite and witherite were deposited, and this occurred in a replacive manner in some instances. In order to deposit As-rich tokyoite at the same time, vanadium and arsenic must have also been carried by and precipitated out of solution. Finally, any excess $\mathrm{SiO}_{2}$ would be deposited in the inner part of zoned vugs as quartz.

In terms of fluid-flow affecting ore mineralogy, evidence exists for replacement and recrystallization processes. The replacement of gangue phases by braunite is evident in one unit of core SLT-015. It is likely that manganese, being mobilized on a local scale as $\mathrm{MnCl}_{2}$ (which is more soluble than $\mathrm{BaCl}_{2}$; see [49]) was precipitated later than $\mathrm{Ba}$ in the hydrothermal system. This would explain the replacement of hydrothermal gangue phases by braunite. Hematite shows various recrystallization textures though this can also be linked to low-grade metamorphism. Where hematite ovoids exist in the ferromanganese matrix of core SLT-015, many have an outer rim of Mn-rich material which can be interpreted as replacement rims due to localised manganese mobility. The presence of hollandite in parts of drill core SLT-015 account for elevated barium concentrations in bulk-rock geochemical analyses of some samples. This mineral gives further evidence for the presence of a Ba-rich fluid percolating pervasively through the ores. It also attests to the metastability of $\mathrm{Mn}^{3+}$ in natural minerals. 


\subsection{Manganese Ore Formation in the Postmasburg Manganese Field}

The ore deposits of the PMF are stratigraphically, mineralogically and geochemically variable and complex, and this must be accounted for when developing a genetic model for these deposits. There is general consensus that the protores to the present deposits would have formed in karst environments and that the manganese, iron and the bulk of the silicon were derived, at least partly, in situ from the dolomites of the Campbellrand Subgroup of the Transvaal Supergroup. However, to restrict the source of metals to the Reivilo and Fairfield Formations is to discount some $800 \mathrm{~m}$ of missing dolomitic rock which would otherwise have overlain these formations.

The model presented incorporates ideas of previous authors [1,9] but envelops all deposit types into one inclusive model (Figure 12). It also tentatively provides a source of alkali metals for hydrothermal activity in the PMF. First, the dolomitic rocks of the Campbellrand Subgroup were deposited, followed by BIF of the Asbestos Hills Subgroup (Figure 12A). Tectonic activity led to the development of the regional anticlinal structure known as the Maremane Dome. This tilting and related uplift was followed by erosion of both the Asbestos Hills and underlying Campbellrand Subgroup rocks, prior to the deposition of the Mapedi Formation of the Olifantshoek Supergroup (Figure 12B). This led to the development of a regional erosional unconformity. During this period, both surficial and subsurface karstification processes began within the dolomitic rocks of the Campbellrand Subgroup. As described by Plehwe-Leisen and Klemm [9], the karstification would have preferentially (though not exclusively) developed along zones of weakness caused by tectonic activity. Where BIF overlay the dolomites, sub-surface cave systems developed. It was during this period of erosion that the Doornfontein conglomerates were deposited within the sinkholes. Clearly, the residual contents of karstic sinkholes are not only a function of the composition of the rocks being dissolved at the time, but also of the composition of previously overlying dolomites that had already been dissolved.

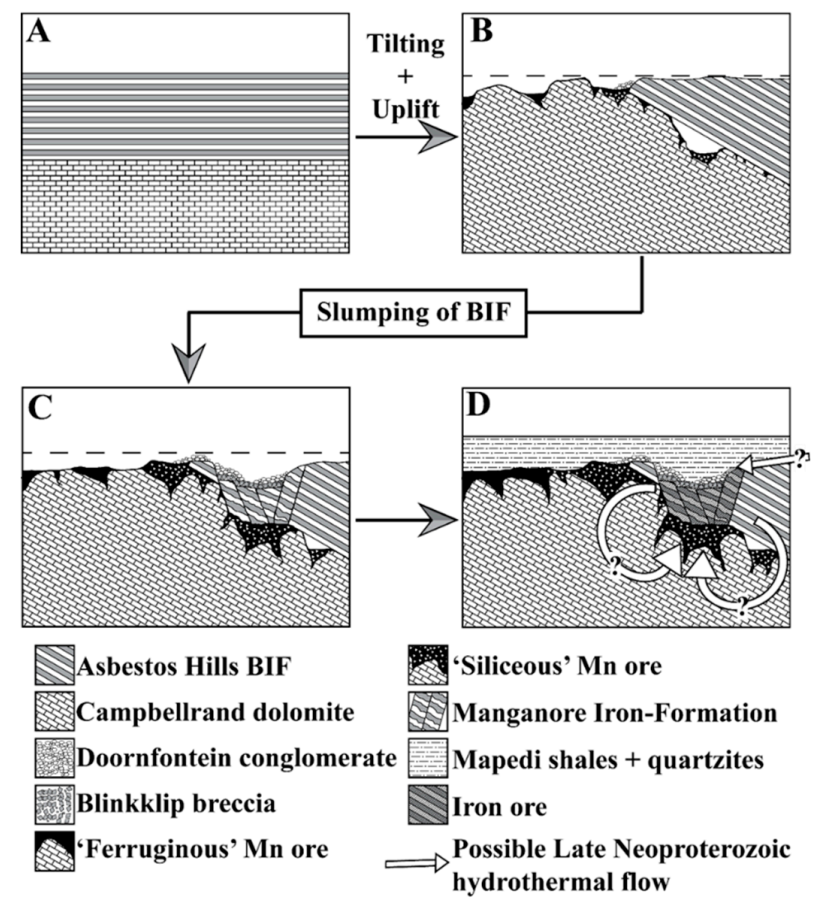

Figure 12. Model of ore formation for all ancient manganese deposits of the Postmasburg manganese field. A. Deposition of the Campbellrand and Asbestos Hills Subgroups. B. Tilting and uplift followed by erosion and dissolution of the Campbellrand dolomites. C. Continued dissolution and slumping of BIF into karstic sinkholes. Deposition of the Blinkklip breccia and Doornfontein conglomerate. D. Fluid influx, upgrading of BIF to Fe-ore and leaching of $\mathrm{Na}$, Si, and $\mathrm{K}$. Related metasomatism of manganese ores and deposition of alkali assemblages. 
Continued dissolution caused the development of new sinkholes and an increase in size of existing ones. The increased size of cavity systems below the Asbestos Hills Subgroup caused the BIF to destabilize, collapse and slump into the underlying karstic depressions (Figure 12C). It was during this process that the so-called Blinklip iron-formation breccia would have formed [15]. The shales and quartzites of the Mapedi Formation were later deposited over the erosion surface. Dissolution continued during this phase of deposition and karstic depressions continued to deepen, thus causing syn-depositional faulting and slumping of the Mapedi Formation itself (Figure 12D).

Hydrothermal overprinting and likely upgrading of the ore through Mn remobilisation would have occurred during a regional fluid-flow event in the late Neoproterozoic. This event likely involved evolved, warm, oxidized, basinal brines that were enriched in alkalis and alkali earths, such as $\mathrm{Na}, \mathrm{K}$, $\mathrm{Ba}, \mathrm{Li}$ and $\mathrm{Sr}$. These brines were responsible for alkali metasomatic alteration of the PMF ores and may have even contributed, in part, to further dissolution of Campbellrand dolomites. The source of metals enriched in the hydrothermal fluid is still largely undetermined, but a likely source of sodium and potassium could have been primary evaporitic material from the Campbellrand carbonate rocks and possibly also the Asbestos Hills BIF.

\section{Conclusions}

The results of this study have highlighted the need for revision of the pigeon-hole-type classification of the PMF manganese ores into Western and Eastern Belt or ferruginous and siliceous ores. The mineralogical and geochemical variability and complex stratigraphic setting of these deposits calls for a more holistic approach to modelling their genesis, with renewed emphasis on understanding the influence of the hydrothermal component of their ore-forming history. The complex gangue assemblages described and reported here, in conjunction with similar regional mineralogical and geochemical evidence and new age constraints reinforcing previously published ages, provide further evidence for a major hydrothermal event that affected the rocks of the Transvaal Supergroup in the late Neoproterozoic. The timing may be tentatively interpreted as the far-field response to amalgamation of the Gondwanan supercontinent and may have resulted in metasomatic effects with respect to $\mathrm{Mn}$ and Fe recorded over distances in excess of $100 \mathrm{~km}$ from the PMF to the KMF. Nevertheless, key local-scale structural controls of hydrothermal fluid-flow are yet to be conclusively identified, while the ore-forming role of hydrothermal activity during earlier events of regional structural deformation is still largely unexplored. The genesis of the manganese deposits of the PMF and adjacent massive iron ore deposits alike, undoubtedly remains a very fertile topic for future research.

Supplementary Materials: The following are available online at http://www.mdpi.com/2075-163X/9/7/408/s1, Additional information and raw analytical data not displayed in the main text are included in the Supplementary Materials.

Author Contributions: B.J.F. carried out the research and wrote the manuscript. M.J.T. and M.S. produced the feldspar ages and prepared the corresponding text and interpretations. H.T. conceived the research project and contributed to the interpretations and writing.

Funding: This research was funded through an MSc bursary by the company Angloamerican.

Acknowledgments: H. T. acknowledges generous funding by ASSMANG Ltd. for the establishment of research unit PRIMOR at Rhodes University. We wish to thank Angloamerican for providing formal financial support to B.J.F. and H.T. for the execution of this research. Christina Gunter is thanked for her help and guidance with the electron probe micro-analyses.

Conflicts of Interest: The authors declare no conflict of interest.

\section{References}

1. Gutzmer, J.; Beukes, N.J. Karst-Hosted Fresh-Water Paleoproterozoic Manganese Deposits, Postmasburg, South Africa. Econ. Geol. 1996, 91, 1435-1454. [CrossRef]

2. Hall, A.L. The manganese deposits near Postmasburg, West of Kimberley. Trans. Geol. Soc. South Afr. 1926, $29,17-46$. 
3. Nel, L.T. The Geology of the Postmasburg Manganese Deposits and the Surrounding Country: An Explanation of the Geological Map; Special Publication; Geological Survey of South Africa, Government Printer: Pretoria, South Africa, 1928.

4. Kaiser, E. Zur Frage der Entstehung der Manganerzlagerstätten von Postmasburg in Griqualand-West, Südafrika: Neues. Jb. Min. Beil. Bd. 1931, 64.

5. Schneiderhöhn, H. Mineralbestand und Gefüge der Manganerze von Postmasburg, Griqualand West, Südafrika: Neus. Jb. Min. Beil. Bd. 1931, 64.

6. Du Toit, A.L. The manganese deposits of Postmasburg, South Africa. Econ. Geol. 1933, 28, 95-122. [CrossRef]

7. De Villiers, J.E. The origin of the iron and manganese deposits in the Postmasburg and Thabazimbi areas. Trans. Geol. Soc. South Afr. 1944, 47, 123-135.

8. De Villiers, J. Manganese Deposits of the Union of South Africa; Handbook 2; Geological Survey of South Africa, Government Printer: Pretoria, South Africa, 1960.

9. Von Plehwe-Leisen, E; Klemm, D.D. Geology and ore genesis of the manganese ore deposits of the Postmasburg manganese-field, South Africa. Miner. Depos. 1995, 30, 257-267. [CrossRef]

10. De Villiers, J.E. The manganese deposits of Griqualand West, South Africa; some mineralogic aspects. Econ. Geol. 1983, 78, 1108-1118. [CrossRef]

11. Nell, J.; Pollak, H.; Lodya, J.A. Intersite cation partitioning in natural and synthetic alpha-( $\mathrm{Fe}, \mathrm{Mn})_{2} \mathrm{O}_{3}$ (bixbyite) solid solutions determined from ${ }^{57} \mathrm{Fe}$ Mössbauer spectroscopy. Hyperfine Interact. 1994, 91, 601-605. [CrossRef]

12. von Plehwe-Leisen, E. Geologische und erzpetrographische Untersuchungen der Manganerze des Postmasburgfeldes, Nördliche Kapprovinz, Südafrika. Unpublished Ph.D. Thesis, Ludwig-Maximilians Universität, München, Germany, 1985; 129p.

13. Moore, J.M.; Kuhn, B.K.; Mark, D.F.; Tsikos, H. A sugilite-bearing assemblage from the Wolhaarkop breccia, Bruce iron-ore mine, South Africa: Evidence for alkali metasomatism and ${ }^{40} \mathrm{Ar}-{ }^{39} \mathrm{Ar}$ dating. Eur. J. Miner. 2011, 23, 661-673. [CrossRef]

14. Van Niekerk, H.S. The origin of the Kheis Terrane and its relationship with the Archean Kaapvaal Craton and the Grenvillian Namaqua Province in southern Africa. Unpublished Ph.D. Thesis, University of Johannesburg, Johannesburg, South Africa, 2006.

15. Beukes, N.J. The Transvaal Sequence in Griqualand West. In Mineral Deposits of Southern Africa; Anhaeusser, C.R., Maske, S., Eds.; Geological Society of South Africa: Johannesburg, South Africa, 1986.

16. Beukes, N.J. Facies relations, depositional environments and diagenesis in a major early Proterozoic stromatolitic carbonate platform to basinal sequence, Campbellrand Subgroup, Transvaal Supergroup, Southern Africa. Sediment. Geol. 1987, 54,1-46. [CrossRef]

17. Altermann, W.; Siegfried, H.P. Sedimentology and facies development of an Archaean shelf: carbonate platform transition in the Kaapvaal Craton, as deduced from a deep borehole at Kathu, South Africa. J. Afr. Earth Sci. 1997, 24, 391-IN4. [CrossRef]

18. Beukes, N.J. Palaeoenvironmental setting of iron-formations in the depositional basin of the Transvaal Supergroup, South Africa. In Iron-formations: Facts and Problems; Trendall, A.F., Morris, R.C., Eds.; Elsevier: Amsterdam, Germany, 1983.

19. Kendall, B.; Van Acken, D.; Creaser, R.A. Depositional age of the early Paleoproterozoic Klipputs Member, Nelani Formation (Ghaap Group, Transvaal Supergroup, South Africa) and implications for low-level Re-Os geochronology and Paleoproterozoic global correlations. Precambrian Res. 2013, 237, 1-12. [CrossRef]

20. Polteau, S.; Moore, J.M.; Tsikos, H. The geology and geochemistry of the Palaeoproterozoic Makganyene diamictite. Precambrian Res. 2006, 148, 257-274. [CrossRef]

21. Bleeker, W.; Söderlund, U.; Bekker, A.; Gumsley, A.P.; Chamberlain, K.R.; De Kock, M.O.; Larsson, E.R. Timing and tempo of the Great Oxidation Event. Proc. Natl. Acad. Sci. 2017, 114, 1811-1816.

22. Cornell, D.H.; Schiitte, S.S.; Eglington, B.L. The Ongeluk basaltic andesite formation in Griqualand West, South Africa: Submarine alteration in a 2222 Ma Proterozoic sea. Precambrian Res. 2016, 79, 101-123. [CrossRef]

23. Tsikos, H.; Moore, J.M. Petrography and geochemistry of the Paleoproterozoic Hotazel Iron-Formation, Kalahari manganese field, South Africa; implications for Precambrian manganese metallogenesis. Econ. Geol. 1997, 92, 87-97. [CrossRef] 
24. Tsikos, H.; Moore, J.; Harris, C. Geochemistry of the Palæoproterozoic Mooidraai Formation: Fe-rich limestone as end member of iron formation deposition, Kalahari Manganese Field, Transvaal Supergroup, South Africa. J. Afr. Earth Sci. 2001, 32, 19-27. [CrossRef]

25. Fairey, B.; Tsikos, H.; Corfu, F.; Polteau, S. U-Pb systematics in carbonates of the Postmasburg Group, Transvaal Supergroup, South Africa: Primary versus metasomatic controls. Precambrian Res. 2013, 231, 194-205. [CrossRef]

26. Moen, H.F.G. The Olifantshoek Supergroup. In The Geology of South Africa; Johnson, M.R., Anhaeusser, C.R., Thomas, R.J., Eds.; Geological Society of South Africa: Johannesburg, Germany, 2006.

27. Beukes, N.; Gutzmer, J.; Mukhopadhyay, J. The geology and genesis of high-grade hematite iron ore deposits. Appl. Earth Sci. 2003, 112, 18-25. [CrossRef]

28. Gutzmer, J.; Beukes, N.J. Mineralogy and mineral chemistry of oxide-facies manganese ores of the Postmasburg manganese field, South Africa. Miner. Mag. 1997, 61, 213-231. [CrossRef]

29. Costin, G.; Fairey, B.; Tsikos, H.; Gucsik, A. Tokyoite, As-rich Tokyoite, and noélbensonite: New occurences from the Postmasburg Manganese Field. Northern Cape Province, South Africa. Can. Mineral. 2015, 53, 981-990. [CrossRef]

30. Anthony, J.W.; Bideaux, R.A.; Bladh, K.W.; Nichols, M.C. Handbook of Mineralogy; Mineralogical Society of America: Chantilly, VA, USA, 2003.

31. Gottardi, G.; Galli, E. Natural Zeolites; Springer-Verlag: Berlin, Germany, 1985.

32. Vlasov, K.A.; Kuz'menko, M.Z.; Es'kova, E.M. The Lovozero Alkali Massif, 1st ed.; Oliver and Boyd Ltd.: London, UK, 1966.

33. Dixon, R. Sugilite and associated metamorphic silicate minerals from Wessels mine, Kalahari manganese field. Bull. Geol. Surv. South Afr. 1989, 93, 1-47.

34. Deer, W.A.; Howie, R.A.; Zussman, J. An. Introduction to the Rock-Forming Minerals, 2nd ed.; Pearson Education Limited: Harlow, UK, 1992.

35. Gutzmer, J.; Beukes, N.J. Mineral paragenesis of the Kalahari managanese field, South Africa. Ore Geol. Rev. 1996, 11, 405-428. [CrossRef]

36. Zen, E.; Ross, M.; Bearth, P. Paragonite from Täsch Valley near Zermatt, Switzerland. Am. Mineral. 1964, 49, 183-190.

37. Campbell, S.W.; Bannister, F.A.; Hey, M.H. Banalsite, a new barium-feldspar from Wales. Miner. Mag. 1944, $27,33$.

38. Liferovich, R.P.; Mitchell, R.H.; Zozulya, D.R.; Shpachenko, A.K. Paragenesis and composition of banalsite, stronalsite, and their solid solution in nepheline syenite and ultramafic alkaline rocks. Can. Mineral. 2006, 44, 929-942. [CrossRef]

39. Matsubara, S. The mineralogical implication of barium and strontium silicates. Bull. Natn. Sci. Mus. 1985, 11C, 37-95.

40. Kawachi, Y.; Coombs, D.S.; Miura, H. Noélbensonite, a new BaMn silicate of the lawsonite structure type, from the Woods mine, New South Wales, Australia. Mineral. Mag. 1996, 60, 369-374. [CrossRef]

41. Armbruster, T.; Oberhänsli, R.; Bermanec, V.; Dixon, R. Hennomartinite and kornite, two new $\mathrm{Mn}^{3+}$ rich silicates from the Wessels Mine, Kalahari, South Africa. Schweiz. Mineral. Petrogr. Mitt. 1993, 73, 349-355.

42. Matsubara, S.; Miyawaki, R.; Yokoyama, K.; Shimizu, M.; Imai, H. Tokyoite $\mathrm{Ba}_{2} \mathrm{Mn}^{3+}\left(\mathrm{VO}_{4}\right)_{2}(\mathrm{OH})$, a new mineral from the Shiromaru mine, Okutama, Tokyo, Japan. J. Mineral. Petrogr. Sci. 2004, 99, 363-367. [CrossRef]

43. De Villiers, J.E. Gamagarite, a new vanadium mineral from the Postmasburg manganese deposits. Am. Mineral. 1943, 28, 329-335.

44. De Villiers, J.E. Some minerals occurring in South African manganese deposits. Trans. Geol. Soc. South Afr. $1945,48,17-25$.

45. Tsikos, H.; Moore, J.M. Sodic metasomatism in the Palaeoproterozoic Hotazel iron-formation, Transvaal Supergroup, South Africa: implications for fluid-rock interaction in the Kalahari manganese field. Geofluids 2005, 5, 264-271. [CrossRef]

46. Cairncross, B.; Tsikos, H.; Harris, C. Prehnite from the Kalahari manganese field, South Africa, and its possible implications. South Afr. J. Geol. 2000, 103, 231-236. [CrossRef] 
47. Gnos, E.; Armbruster, T.; Villa, I.M. Norrishite, $\mathrm{K}\left(\mathrm{Mn}^{3+}{ }_{2} \mathrm{Li}\right) \mathrm{Si}_{4} \mathrm{O}_{10}(\mathrm{O})_{2}$, an oxymica associated with sugilite from Wessels Mine, South Africa: Crystal chemistry and ${ }^{40} \mathrm{Ar}-{ }^{39} \mathrm{Ar}$ dating. Am. Mineral. 2003, 88, 189-194. [CrossRef]

48. Dove, P.M.; Nix, C.J. The influence of the alkaline earth cations, magnesium, calcium, and barium on the dissolution kinetics of quartz. Geochim. Cosmochim. Acta 1997, 61, 3329-3340. [CrossRef]

49. Tables of Physical \& Chemical Constants, 16th ed.; Version 1.0; 2.1.4 Hygrometry; Kaye \& Laby Online: Teddington, UK, 2005; Available online: https://web.archive.org/web/20180929085837/http://www.kayelaby. npl.co.uk/ (accessed on 7 June 2012).

(C) 2019 by the authors. Licensee MDPI, Basel, Switzerland. This article is an open access article distributed under the terms and conditions of the Creative Commons Attribution (CC BY) license (http://creativecommons.org/licenses/by/4.0/). 